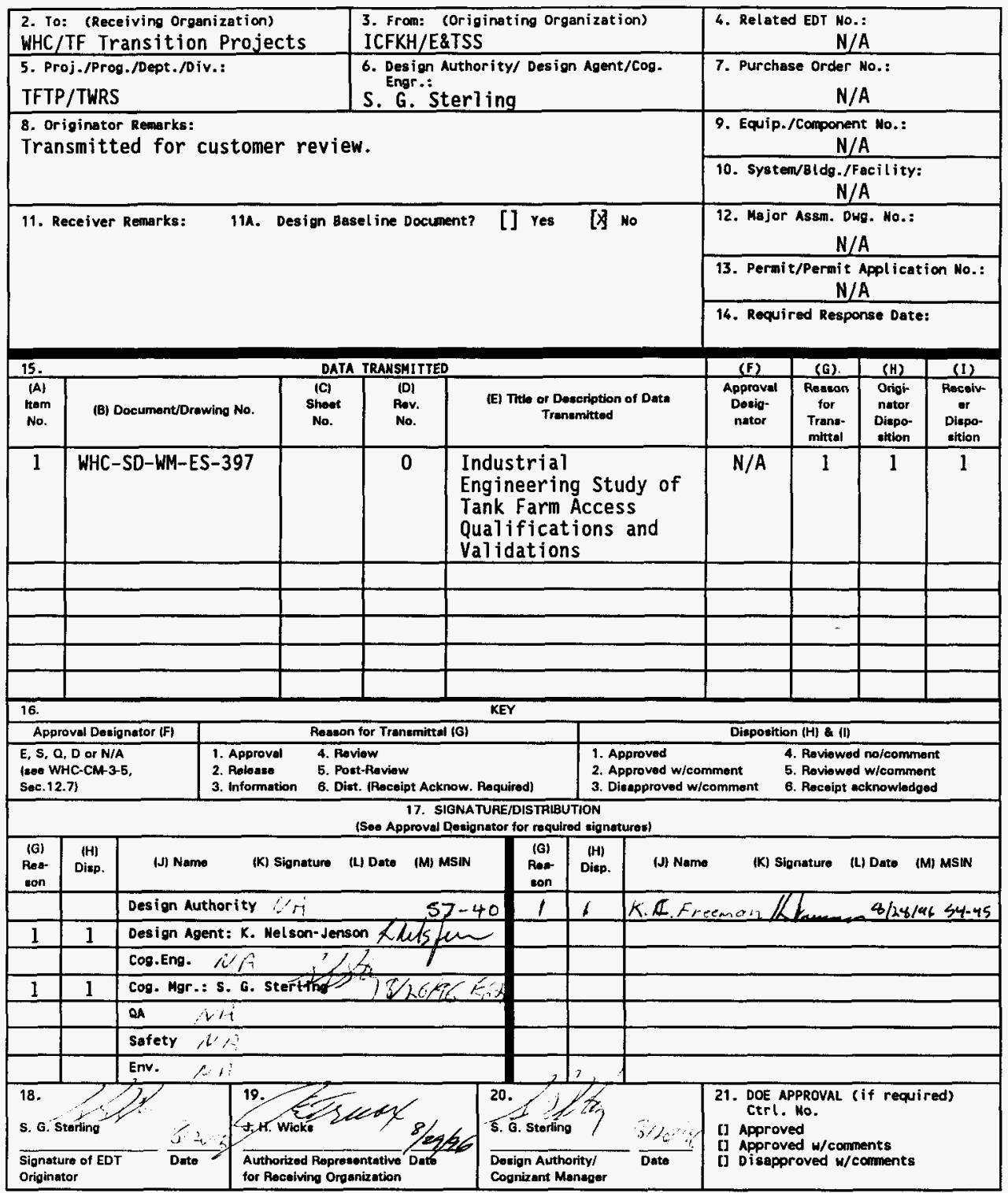




\section{INDUSTRIAL ENGINEERING STUDY OF TANK FARM ACCESS QUALIFICATIONS AND VALIDATIONS}

\section{S. 6. Sterling}

ICF Kaiser Hanford Company, Richland, WA 99352

U.S. Department of Energy Contract DE-ACO6-87RL10930
EDT/ECN: 615551
Org Code: 57B00
UC: 620
B\&R Code: HWHISAHEJO
Charge Code: EK5559
YN0100000

Key Words: Access, Qualifications, Validations, Training, ACES

Abstract: Engineering study of alternatives to reduce costs of validation worker's qualification prior to Tank Farm area access.

\footnotetext{
TRADEMARK DISCLAIMER. Reference herein to any specific comercial product, process, or service by trade name, trademark, manufacturer, or otherwise, does not necessarily constitute or imply its endorsenent, recomendation, or favoring by the United States Government or any agency thereof or its contractors or subcontractors.

Printed in the United States of America. To obtain copies of this document, contact: WHC/BCS Document Control Services, P.0. Box 1970, Mailstop H6-08, Richland WA 99352, Phone (509) 372-2420; Fex (509) 376-4989.
}
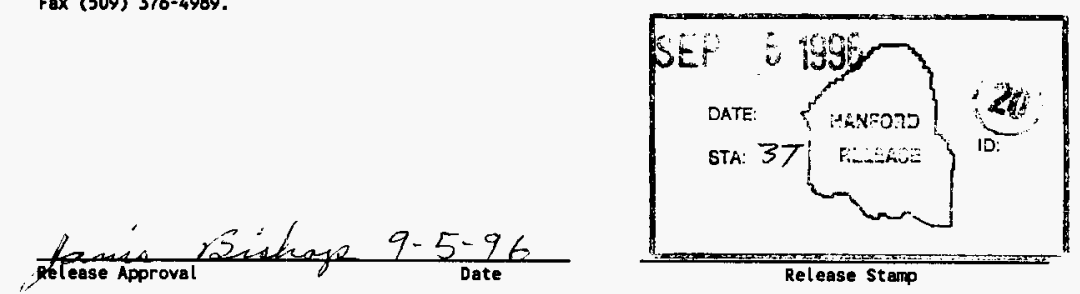
WHC-SD-WM-ES-397, REV 0

Page i of 64

\title{
INDUSTRIAL ENGINEERING STUDY OF TANK FARM ACCESS QUALIFICATIONS AND VALIDATIONS
}

\author{
Issued By: \\ ICF KAISER HANFORD COMPANY \\ July, 1996 \\ for the \\ WESTINGHOUSE HANFORD COMPANY \\ RICHLAND, WASHINGTON \\ and \\ U.S. DEPARTMENT OF ENERGY \\ RICHLAND OPERATIONS OFFICE \\ RICHLAND, WASHINGTON
}


WHC-SD-WM-ES-397, REV 0

Page ii of 64

\section{TABLE OF CONTENTS}

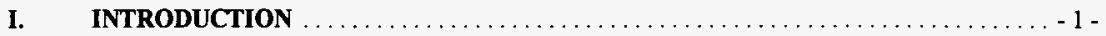

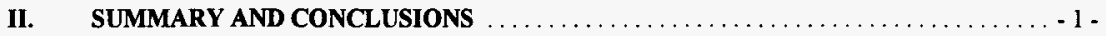

III. DESCRIPTION OF EXISTING PROCESS $\ldots \ldots \ldots \ldots \ldots \ldots \ldots \ldots \ldots \ldots \ldots \ldots \ldots \ldots$ -

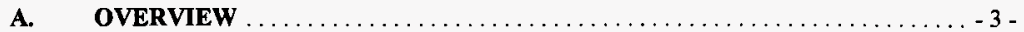

B. ANALYSIS OF EXISTING PROCESS $\ldots \ldots \ldots \ldots \ldots \ldots \ldots \ldots \ldots \ldots \ldots \ldots \ldots$ -

1. Prejob Planning $\ldots \ldots \ldots \ldots \ldots \ldots \ldots \ldots \ldots \ldots \ldots \ldots \ldots \ldots \ldots \ldots \ldots \ldots \ldots, 4$,

2. Crew Assignment $\ldots \ldots \ldots \ldots \ldots \ldots \ldots \ldots \ldots \ldots \ldots \ldots \ldots \ldots \ldots \ldots \ldots, 4$ -

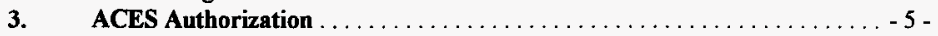

4. Key Control Assignment $\ldots \ldots \ldots \ldots \ldots \ldots \ldots \ldots \ldots \ldots \ldots \ldots \ldots \ldots \ldots \ldots \ldots, 11-$

5. Enter Controlled Work Area $\ldots \ldots \ldots \ldots \ldots \ldots \ldots \ldots \ldots \ldots \ldots, 13$ -

6. Perform Work $\ldots \ldots \ldots \ldots \ldots \ldots \ldots \ldots \ldots \ldots \ldots \ldots \ldots, \ldots, 14$ -

7. Exit Controlled Work Area $\ldots \ldots \ldots \ldots \ldots \ldots \ldots \ldots \ldots \ldots \ldots \ldots \ldots \ldots \ldots, 14$ -

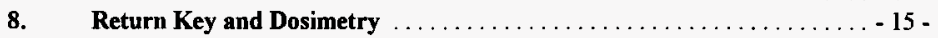

IV. DESCRIPTION OF ALTERNATIVES $\ldots \ldots \ldots \ldots \ldots \ldots \ldots \ldots \ldots \ldots \ldots \ldots \ldots \ldots \ldots$ -

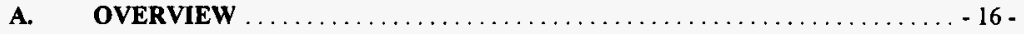

B. ANALYSIS OF ALTERNATIVES $\ldots \ldots \ldots \ldots \ldots \ldots \ldots \ldots \ldots \ldots \ldots \ldots \ldots \ldots \ldots \ldots \ldots$ -

1. Administrative Improvements To Current Process ............... - 19 -

a. Consolidate/Relocate ACES, Key Control and Radio Checkout Stations

..................................... 19 -

b. Prejob Qualification Verification $\ldots \ldots \ldots \ldots \ldots \ldots \ldots \ldots \ldots \ldots \ldots \ldots \ldots \ldots, 22$ -

c. Formal Training For ACES Users $\ldots \ldots \ldots \ldots \ldots \ldots \ldots \ldots \ldots \ldots \ldots \ldots$ - 25 -

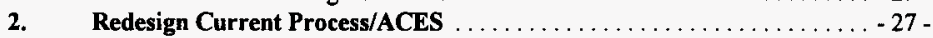

a. Decentralize/simplify ACES ...................... - 27 -

b. Decentralize Key Control $\ldots \ldots \ldots \ldots \ldots \ldots \ldots \ldots \ldots \ldots \ldots . \ldots \ldots$. 33 -

c. Redesign Training Records Information (TRI) System ......... - 35 -

d. Implement Electronic Dosimetry ................... - 39 -

3. Phased Replacement with Automated Site Entry System .......... - 42 -

a. Implement Alternative $1 \ldots \ldots \ldots \ldots \ldots \ldots \ldots \ldots \ldots \ldots \ldots \ldots \ldots, 42$ -

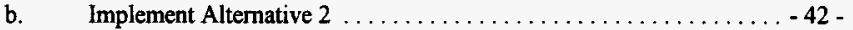

c. Implement Automated Site Entry Pilot/Prototype--Single Farm . . . . - 42 -

d. Implement Automated Site Entry-- All Locations ............. - 45 -

4. Replace with Smart Card Site Entry System ................. - 48 -

5. Purchase and Implement Commercial System (Replace Existing) ...... - 55 -

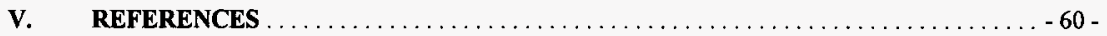

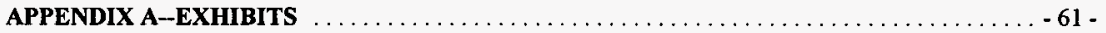

EXHIBIT I - SERVICE LINE PROCESSING $\ldots \ldots \ldots \ldots \ldots \ldots \ldots \ldots \ldots \ldots \ldots, 61$ -

EXHIBIT II-- ACES PROCESS SEQUENCE $\ldots \ldots \ldots \ldots \ldots \ldots \ldots \ldots \ldots \ldots \ldots, 62$ - 
WHC-SD-WM-ES-397, REV 0

Page iii of 64

EXHIBIT III-- ACES OVERVIEW $-64-$ 


\section{INDUSTRIAL ENGINEERING STUDY OF \\ TANK FARM ACCESS \\ QUALIFICATIONS AND VALIDATIONS}

\section{INTRODUCTION}

This study identifies inefficiencies in the current process of qualifying workers for entry into restricted work areas in the Hanford site tank farms, and to explore alternatives to the existing process. The information used in the study was obtained through a one week observation period of the Access Control Entry System (ACES) for 200 W Area Tank Farms, review of records in the ACES and interviews with selected users within Westinghouse Hanford Company (WHC) and ICF Kaiser Hanford (ICF KH.) The study indicates improvements in procedures and equipment could save $\$ 47.8$ million (net) over a seven year life cycle period.

\section{SUMMARY AND CONCLUSIONS}

To ensure worker safety and compliance to conduct of operations objectives, it is essential to validate worker qualifications prior to entrance to Hanford's site hazardous work areas. The current process meets these objectives, but it is costly in terms of time-consuming activities and worker idle time. Depending on many factors, including area entry requirements, type of task, and daily tank farm entry fluctuations, a worker may be nonproductive (not directly working on the task at hand) from two to five hours a day. Extraordinary cases may result in an entire crew being non-productive an entire shift.

There is no single alternative which eliminates all inefficiencies. A range of alternatives providing increasing levels of saving, with proportional levels of capital outlay and process change has been established. A single recommended alternative is not provided within the scope of this study. The study provides quantitative and qualitative input to the Tank Waste Remediation System (TWRS) management and planning. The alternative decision requires program management consideration of factors such as funding availability, labor agreements, staff reduction goals, and contractor reorganization.

Table 1 provides a synopsis of the alternatives considered, cost of implementation, annualized savings, and life cycle savings (assumed to be seven years.) 


\begin{tabular}{|c|c|c|c|c|c|c|}
\hline Alternative & Description & $\begin{array}{l}\text { Cost of } \\
\text { Implementation }\end{array}$ & $\begin{array}{l}\text { Annual } \\
\text { Reoccurring } \\
\text { Costs' }\end{array}$ & $\begin{array}{l}\text { lst Year } \\
\text { Savings }\end{array}$ & $\begin{array}{l}\text { LifeCycle } \\
\text { Savings }(7 \mathrm{yr})^{3}\end{array}$ & $\begin{array}{l}\text { LCS/IC } \\
\text { Ratio }^{+}\end{array}$ \\
\hline 0.00 & Do Nothing (eristing process baseline) & NA & NA & NA & NA & NA \\
\hline 1 & $\begin{array}{l}\text { Administrative Improvements To Current } \\
\text { Process }\end{array}$ & s196k & 57.5k & $\$ 1,742 k$ & S12,970k & 66 \\
\hline $1 . \mathrm{a}$ & $\begin{array}{l}\text { Consolidate/Relocate Access Control Entry } \\
\text { System (ACES) and Key Control Stations }\end{array}$ & $\$ 18.5 \mathrm{k}$ & No Change & \$596k & $\$ 4,281 k$ & 230 \\
\hline 1.6 & Pre-job Qualification Verification & $\$ 115 k$ & $\$ 2.5 \mathrm{k}$ & $\$ 1,146 \mathrm{k}$ & $\$ 8,689 \mathrm{k}$ & 75 \\
\hline $1 . c$ & $\begin{array}{l}\text { Formal Training for ACES Users, } \\
\text { Including TWRS Planners, Supervision } \\
\text { and/or PICS }\end{array}$ & $\$ 62 k$ & \$5k & Unknown & Unknown & Unknwn \\
\hline 2 & Redesign Current Process/ACES System & s1,396k & S372k & $\$ 3,811 k$ & $\$ 32,821 k$ & 24 \\
\hline $2 . \mathrm{a}$ & Decentralize/simplify ACES & $\$ 400 k$ & $\$ 229 k$ & $\$ 3,314 \mathrm{k}$ & $\$ 24,220 \mathrm{k}$ & 60 \\
\hline 2.b & Decentralize Key Control & $\$ 6.8 \mathrm{k}$ & No Change & $\$ 607 \mathrm{k}$ & $\$ 4,292 \mathrm{k}$ & 630 \\
\hline $2 . c$ & $\begin{array}{l}\text { Redesign Training Records Information } \\
\text { (TRD) System }\end{array}$ & $\$ 459 \mathrm{k}$ & $\$ 112 k$ & (\$186k) & $\$ 780 \mathrm{k}$ & 1.7 \\
\hline $2 . d$ & Implement Electronic Dosimetry & $\$ 530 \mathrm{k}$ & $\$ 31 \mathrm{k}$ & $\$ 76 \mathrm{k}$ & $\$ 3,529 \mathrm{k}$ & 6.6 \\
\hline 3 & $\begin{array}{l}\text { Phased Replacement with Automated Site Entry } \\
\text { System }\end{array}$ & $\$ 2,154 k$ & S438k & $\$ 7,243 k$ & $\$ 48,007 k$ & 22 \\
\hline 3.1 & Implement Alternative 1 & \$196k & $\$ 7.5 \mathrm{k}$ & $\$ 1,742 k^{5}$ & $\$ 1,742 k^{5}$ & 8 \\
\hline 3.2 & Implement Alternative 2 & $\$ 1,396 \mathrm{k}$ & $\$ 372 k$ & $\$ 3,811 \mathrm{k}$ & $\$ 32,821 \mathrm{k}$ & 24 \\
\hline 3.3 & $\begin{array}{l}\text { Implement Automated Site Entry } \\
\text { Pilot/Prototype- Single Farm }\end{array}$ & S233K & None & NA & $\mathrm{NA}$ & NA \\
\hline 3.4 & $\begin{array}{l}\text { Implement Automated Site Entry - All } \\
\text { Appropriate Locations }\end{array}$ & $\$ 327 k$ & S58k & $\$ 1,690 \mathrm{k}$ & $\$ 13,444 k$ & 41 \\
\hline 4 & Replace with Smart Card Site Entry System & $\$ 2,516 \mathrm{k}$ & S561k & $\$ 4,091 \mathrm{k}$ & $\$ 40,377 k$ & 16 \\
\hline 5 & $\begin{array}{l}\text { Purchase and Implement Commercial } \\
\text { Entrance/Radiological Control System (Replace } \\
\text { Existing) }\end{array}$ & $54,364 k$ & s346k & $\$ 2,215 \mathrm{k}$ & $\$ 39,605 k$ & 9 \\
\hline
\end{tabular}

Table 1

Net.

2 Net: Calculated as: 1st Year Savings - Implementation Costs

3 Net: Calculated as: Lifecycle Savings (7 year) - Implementation Costs - Lifecycle Reoccuring Costs

$4 \quad$ Life Cycie Savings (LCS) to Implementation Cost (IC) ratio.

5 Under Alternative 3, Altemative 3.1 is an interim cost saving measure to be in effect during the engineering and construction of Alternative 3.2. It is replaced by Alternative 3.2, and has no savings value beyond the implementation schedule of Alternative 3.2 (approx. 1 year.) The annual savings (net) in this case is the first year and life cycle savings, and is calculated as: Annual Savings (gross) - Implementation Costs- 1 Year Reoccurring Costs. 


\section{DESCRIPTION OF EXISTING PROCESS}

\section{A. OVERVIEW}

The current process for a work crew to prepare for and perform work in radiological or hazardous controlled areas requires several preliminary steps. Prior to the day a task is to be performed, a job planner, task leader or person in charge (PIC) prepares a work package for all major work efforts. Crew assignments may be made prior to or on the work date, depending on the work package, by the supervisor or the PIC. A prejob briefing is held to review the applicable job safety analysis (JSA), radiation work procedures (RWP) and other information. The crew then travels to one of six centralized Access Control Entry System (ACES) stations, which in many cases is a multi-kilometer distance requiring vehicles. At the ACES station, qualifications for the entry and work to be performed are validated for each individual. If the qualifications are met, dosimetry is issued, if required (some entry is into non-radiological, hazardous areas.) The crew proceeds to obtain a key from a key control station which is typically located in another location. Once a key is obtained, the crew travels to the controlled work area, with the key used to unlock the change trailer (entrance to a tank farm complex) or gate. Log entries are made, and the crew changes into the required protective clothing and safety equipment. The actual work area is entered, and work is performed. The work day is concluded by the crew returning the key and pocket dosimetry ${ }^{6}$. Figure 1 provides an overall process flow path for a typical work day of a work crew.

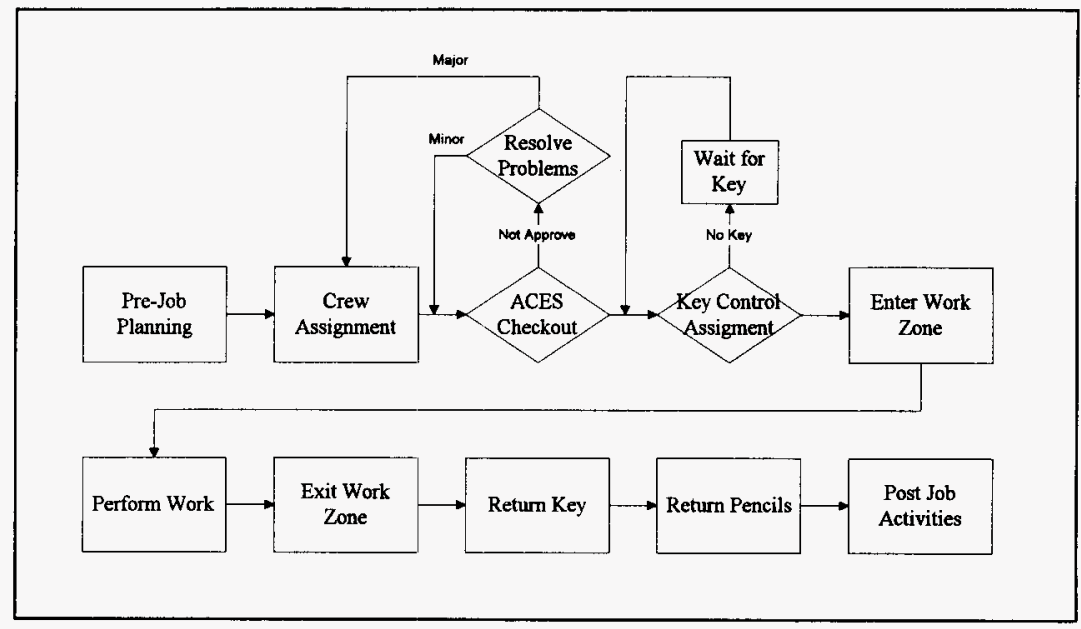

Figure 1 


\section{B. ANALYSIS OF EXISTING PROCESS}

\section{Prejob Planning?}

A job planner, task leader, or PIC prepares a work package for all major work efforts. The work package includes the appropriate documentation, including permits, type of worker, procedures and RWP's. Approval is obtained on the work package from the work area and health physics technologist (HPT) ${ }^{8}$ management.

\section{Noted Problems}

- Worker training required to perform work or obtain zone access is sometimes not scheduled prior to prejob planning. The result can be an individual spending several work days/weeks to complete the series of courses necessary for access qualification and type-of-work requirements addressed in the procedures (RWP and/or Tank Farm Health and Safety Plan, reference 4.)

- For this study, knowledge and assurance of workers' qualifications were considered part of prejob planning and activities. In many cases, the supervisor, job planner or PIC relies on the ACES station check to ensure worker qualification. This causes delay and idle time of workers that could be averted by some process of qualification validation in the prejob planning process. ACES does have a "pre plan comparison check" function for planners and/or supervisors, but it is rarely used. Interviews suggested the lack of use was a result of the ACES user interface complexity, slow response time of ACES, and lack of available training on the ACES.

\section{Crew Assignment ${ }^{7,43}$}

The process step "crew assignment" has four sub-processes or functions.

- Change to initial work clothing (e.g. blue overalls)

- Crew assignment

- Crew assembly

- Prejob briefing

Crew assignments typically are made on the actual work date at the beginning of shift, although prior assignment may be made in some situations ${ }^{9}$. Crews, including health-physics technologists, shift supervisor, and/or PIC are assembled for a prejob briefing. The prejob briefing subjects include task description, division of labor, safety, radiological limits and procedures, hazardous materials handling, individual tasks, and responsibilities. This ensures that all involved personnel are aware of their responsibilities as well as any particular hazards associated with the work.

During the observation period, a crew size from one to sixteen was observed, with an average crew size of eight

Detailed analysis of prejob planning and crew assignment is not part of the scope of this study, and were not assessed as being significant targets of savings opportunity. 


\section{Noted Problems}

- Observation did not find integration or coordination of work assignments between projects, or between operations activities and projects. This was supported by interview comments.

\section{ACES Authorization}

The process step "ACES authorization" has seven subprocesses or functions.

- Travel to ACES station

- wait in line for other crews

- ACES qualification checkout

- Pocket dosimetry checkout/entry into ACES

- Resolve major declination

- Resolve minor declination

- Manning ACES station

After the prejob briefing, the crew travels to the ACES station to obtain pocket dosimetry and to verify controlled work area access permits. In some cases, the ACES station is within short walking distance of the crew assembly area. In most cases, travel and transportation of the crew is required.

The crew reports to the ACES station, joins a queue of other workers, and waits for each individual in the crew to obtain work authorization. At one of the six major ACES stations servicing tank farm operations, the ACES operator (an HPT) obtains the workers payroll number, work location, applicable RWP and/or HASP, and the activities to be performed. Each worker is required to sign a written log that records that the worker has read the applicable RWP. The ACES operator enters the appropriate information into ACES. ACES searches the following information for each worker:

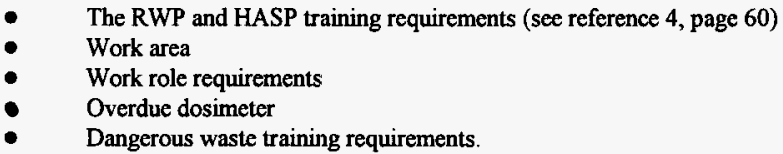

These conditions are automatically compared with:

Authorizations to perform work
The worker's training qualifications
The worker's medical qualifications
Definition of the work to be performed and protective gear to be used
The state of the worker's dosimetry
Current radiation exposure (dose) for the worker relative to accepted limits.

ACES determines if the worker meets the established requirements and informs the ACES operator. If the worker is validated, the operator issues appropriate dosimetry, usually a pocket-type dosimeter. The ACES operator records the unique pocket dosimetry identification into ACES. For non-radiological zone access, a "BRICK" identification badge is an alternative to obtaining a pocket dosimeter. ${ }^{10}$ This process is repeated for each member of the crew. 
A declination occurs if qualifications of one or more members of the crew cannot be validated. Declinations may be major or minor. The ACES operator will attempt to resolve a minor declination locally. Typical minor declinations include, but are not limited to the following.

- Worker(s) has not read an applicable RWP. A copy of the RWPs are located at the ACES station and the worker(s) typically reads the procedure while the others wait.

- Worker's training completion records are not current on the ACES and TRI databases. In these instances, the worker presents the written record of the completed training course." The ACES station operator can override the record on an exception basis, but cannot modify the base training record.

Major declinations occur when the ACES operator cannot correct the problem and obtain qualification validation for all members of the crew. Typically, the crew cannot continue and must wait for resolution or a replacement worker. These delays in travel time and crew reassignment can take from hours to days to resolve. An individual obtaining work authorization can encounter similar problems. Typical major declinations include, but are not limited to the following.

- Worker(s) does not have a current medical examination, whole body count, or mask fit. These processes can take days to schedule and complete.

- Worker(s) does not have required training, or his/her training qualification has expired. These can take days to weeks to schedule and complete.

In general, individual crew assignments are modified to work around major declinations.

Table 2 provides a synopsis of the functions, associated time and costs of the process step. 


\begin{tabular}{|c|c|c|c|c|c|c|c|}
\hline \multicolumn{3}{|c|}{ Process Step: ACES Authorization } & \multicolumn{5}{|r|}{ Table 2} \\
\hline Function & Op & $\begin{array}{l}\text { Idie } \\
\text { Time }\end{array}$ & $\begin{array}{l}\text { Total } \\
\text { Time }\end{array}$ & Rete ${ }^{14}$ & $\begin{array}{l}\text { Cost/ } \\
\text { Incident }\end{array}$ & $\begin{array}{l}\text { LifeCycle } \\
\text { Cost }(7 \mathrm{yr})^{15}\end{array}$ & comments \\
\hline $\begin{array}{l}\text { Travel to ACES } \\
\text { Station }\end{array}$ & $\begin{array}{l}1.33 \mathrm{hrs} / \\
\text { crew }\end{array}$ & $\begin{array}{l}0.40 \mathrm{hrs} / \\
\text { crew }\end{array}$ & $\begin{array}{l}1.73 \mathrm{hrs} \\
\text { crew }\end{array}$ & $\begin{array}{l}\text { S46.2SI } \\
\mathrm{hr}\end{array}$ & $\$ 80.00$ & 56,931k & $\begin{array}{l}\text { Idle time includes time to gather and } \\
\text { loud crew in vehicle, occasional fueling } \\
\text { of vehicle ( } 1 \text { in } 20 \text { trips) }\end{array}$ \\
\hline $\begin{array}{l}\text { Wait in Line For } \\
\text { Other Crews }\end{array}$ & NA & $\begin{array}{l}1.33 \mathrm{hrs} / \\
\text { crew/s }\end{array}$ & $\begin{array}{l}1.33 \mathrm{hrs} \\
\text { lorew }\end{array}$ & $\begin{array}{l}\$ 46.25 \\
\text { hr }\end{array}$ & $\$ 61.50$ & S5,328k & $\begin{array}{l}\text { Average time crew waits in line for other } \\
\text { crews to complete. }\end{array}$ \\
\hline $\begin{array}{l}\text { ACES Qualification } \\
\text { Checkout }\end{array}$ & $\begin{array}{l}0.4 \mathrm{hrs} \\
/ \text { crew }^{17}\end{array}$ & $\begin{array}{l}2.8 \mathrm{hrs} \\
\text { /crew" }\end{array}$ & $\begin{array}{l}3.2 \text { hrs } \\
\text { /crew }\end{array}$ & $\begin{array}{l}\$ 46.25 \\
\mathrm{hr}\end{array}$ & $\$ 148.00$ & $\$ 12,822 k$ & $\begin{array}{l}\text { Calculated on a mean operational } \\
\text { process time of } 3 \text { minutes per person. }\end{array}$ \\
\hline $\begin{array}{l}\text { Checkout Pocket } \\
\text { Dosimeter }\end{array}$ & $\begin{array}{l}0.13 \mathrm{hrs} \\
\text { /crew }\end{array}$ & $\begin{array}{l}0.93 \mathrm{hrs} \\
\text { /crew }\end{array}$ & $\begin{array}{l}1.06 \mathrm{hrs} \\
\text { lorew }\end{array}$ & $\begin{array}{l}\$ 46.25 \\
\mathrm{hr}\end{array}$ & $\$ 49.00$ & $\$ 4,245 \mathrm{k}$ & $\begin{array}{l}\text { Calculated on a mean operational } \\
\text { process time of } 1 \text { minute per person. }\end{array}$ \\
\hline $\begin{array}{l}\text { Resolve Major } \\
\text { Declination }\end{array}$ & $\begin{array}{l}1.6 \mathrm{hrs} \\
\text { /crew }\end{array}$ & $\begin{array}{l}11.2 \mathrm{hrs} \\
\text { /crew }\end{array}$ & $\begin{array}{l}12.8 \mathrm{hrs} \\
\text { /crew }\end{array}$ & $\begin{array}{l}\$ 46.25 \\
\text { hr }\end{array}$ & $\$ 592.00$ & $\$ 3,448 \mathrm{k}^{19}$ & \\
\hline $\begin{array}{l}\text { Resolve minor } \\
\text { Declination }\end{array}$ & $\begin{array}{l}0.67 \mathrm{hrs} \\
\text { /orew }\end{array}$ & $\begin{array}{l}4.67 \mathrm{hrs} \\
\text { /crew }\end{array}$ & $\begin{array}{l}5.34 \text { hus } \\
\text { /crew }\end{array}$ & $\begin{array}{l}\$ 46.25 \\
\mathrm{hr}\end{array}$ & $\$ 247.00$ & $5450 k^{20}$ & $\begin{array}{l}\text { During the observation period, only five } \\
\text { crews had a minor declination. } \\
\text { Interviews and review of ACES records } \\
\text { indicates this was a exceptional week, } \\
\text { and these declinations occur more } \\
\text { frequently. }\end{array}$ \\
\hline $\begin{array}{l}\text { Manning ACES } \\
\text { station by HPT }\end{array}$ & $\begin{array}{l}64.3 \text { hrs } \\
\text { /wk }\end{array}$ & $\begin{array}{l}175.7 \\
\mathrm{hrs} / \mathrm{wk}\end{array}$ & $\begin{array}{l}240 \text { hrs } \\
/ \text { wk }\end{array}$ & $\begin{array}{l}\$ 44.56 \\
\mathrm{hr}^{21}\end{array}$ & $\begin{array}{l}\$ 10.7 k \\
/ w k\end{array}$ & $\mathbf{S 3 , 8 9 3 \mathbf { k } ^ { 2 2 }}$ & $\begin{array}{l}\text { Assumed for full time manning of six } \\
\text { stations, day shift only. }\end{array}$ \\
\hline
\end{tabular}

Note: All estimated costs are for a typical crew of eight workers.

Op Time-sum of mean time required to perform the operation in hours for a typical crew of eight.

14 Composite rate of all participants including supervision, engineering. HPT and craft as applicable, plus org. overhead (22\%), G\&A (13\%) and $\operatorname{CSP}(2 \%)$. ICF $\mathrm{KH}$ rates are higher.

15 Calculated by CostS/incident x 238 incidents/wk $\times 52$ wks/yr x 7 yrs. All costs are in FY 1996 dollars. Life cycle is for seven years, nonescalated.

16 Calculated as 10 minutes $/$ member $\times 8$ members $/$ crew (ave) $=80 \mathrm{~min} .=1.33 \mathrm{hrs}$

17 Mean collective time crew actually spends interacting with ACES. Calculation based on a mean time to process as 3 minutes per person (not inciuding pocket dosimeter checkout) for a crew of eight. See appendix A, exhibit 1 for formula.

Mean collective time crew spends waiting for others in their crew to process through ACES checkout. Calculation based on a mean time to process as 3 minutes per person (not including pocket dosimeter checkout) for a crew of eight. See appendix A, exhibit 1 for formula.

Calculated by Cost\$incident $\times 16$ incidents/wk x 52 wks/yr $\times 7$ yrs.

Calculated by CostS/incident x $\$$ incidents/wk x $\$ 2$ wks/yr $\times 7$ yrs. 
- Travel to ACES station results in the need for and additional mileage to government vehicles.

ACES operator may not be available in the early morning, close to lunch time or late in the afternoon, which creates idle time for crews (see reference 6.) The frequency and duration of this problem could not be determined during the observation period, thus the study does not quantify the impact.

The idle time (time waiting in line or for the remainder of the crew) calculated is based on a mean crew size of eight. As the crew size grows, the idle time growth is exponential (see Appendix A, Exhibit I for example). Figure 2 shows the total time lost versus crew size. The plot assumes that the average process time for a worker is 3 minutes and there is no access declination for any worker in the group. For example, with a crew of eight, the total process time for this crew size is 24 minutes; but total lost time from all members is 168 minutes.

- A minor query or declination causes a linear increase in idle time for the remaining crew members. For example, a delay time of 12 minutes for one person (e.g., one person must read RWP) in a crew of eight (average number during study period) adds an additional 84 minutes of idle time for the total crew.

- ACES obtains training records from the Training Records Information (TRI) database through batch transfer mode. Records in TRI are manually entered by clerks. Although TRI has a goal of entry within 24 hours, interviews with ACES users indicated delays as great as two weeks. There may be a misperception with training personnel that there is no technical alternative to manual signatures, verification, and data entry. The estimated cost of this issue is included in the minor declination function in table 2.

- ACES stations are currently staffed with HPTs. There is a high peak demand after prejob briefings are completed. Figure 3 shows the service demands for various time periods. From the plot, the demand after 10:00 a.m. on day shift is low, and there may be periods during the shift where there is little ACES station activity $^{23}$. Because of the low demand, there is a strong inclination by HPT management to not staff the ACES stations beyond 10:00 a.m. Yet delays due to non-manned ACES station cause crew idle time to rapidly rise. HPT idle time is included in the "Manning ACES stations" function in table 2.

The ACES user interface uses an older, mainframe (computer) style and technology. The steps required to validate qualifications of a worker require many moves through various menu trees and screens, and many keystrokes $^{24}$. A frequent, well-trained user can become very proficient, but untrained or infrequent users struggle to find all the actions that must be accomplished. See Appendix A, Exhibit II for a description of the ACES clearance procedure. 
- Currently, training for ACES is limited to an occasional training class (scheduled on a as-needed basis) generally with knowledgeable HPTs as instructors and OJT (on-the-job training.) No formal notification process was found. Classes are not targeted and regularly scheduled for particular user types. This can result in delays for both the operator and for waiting workers. For example, increasing the processing time from 3 minutes/person (observed average) to 5 minutes/person from an inexperienced, untrained ACES operator increases the sum of the processing and idle time for the average crew of eight from 192 minutes to 320 minutes. The duration and frequency of this problem was not obtainable during the study time, thus, no quantitative costs could be calculated.

- The 272AW ACES station is pinned into corners that restrict access and processing flow, and is part of the HPT preparation and staging areas. This layout creates confusion and can complicate the requirements clearance process. See reference 6.

- Depending on the type of work (i.e., maintenance or construction) and subcontractor, major declinations (unresolvable issues) force at least the affected individual, and sometimes the entire work crew, to go back to their assignment station to resolve the declination with the manager or regroup. This course of action causes significant lost time.

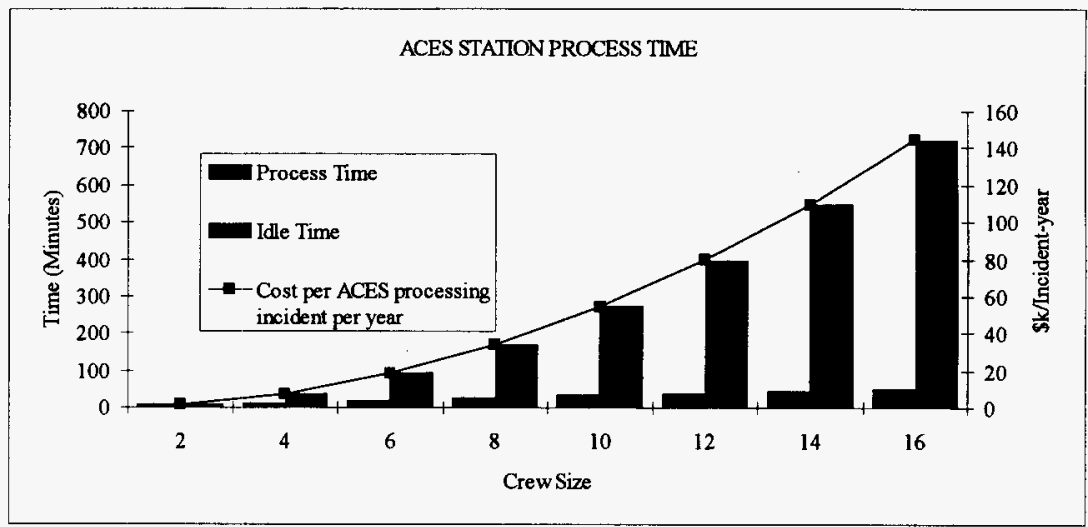

Figure 2 Time Utilization Profile at an ACES Station With No Declinations 


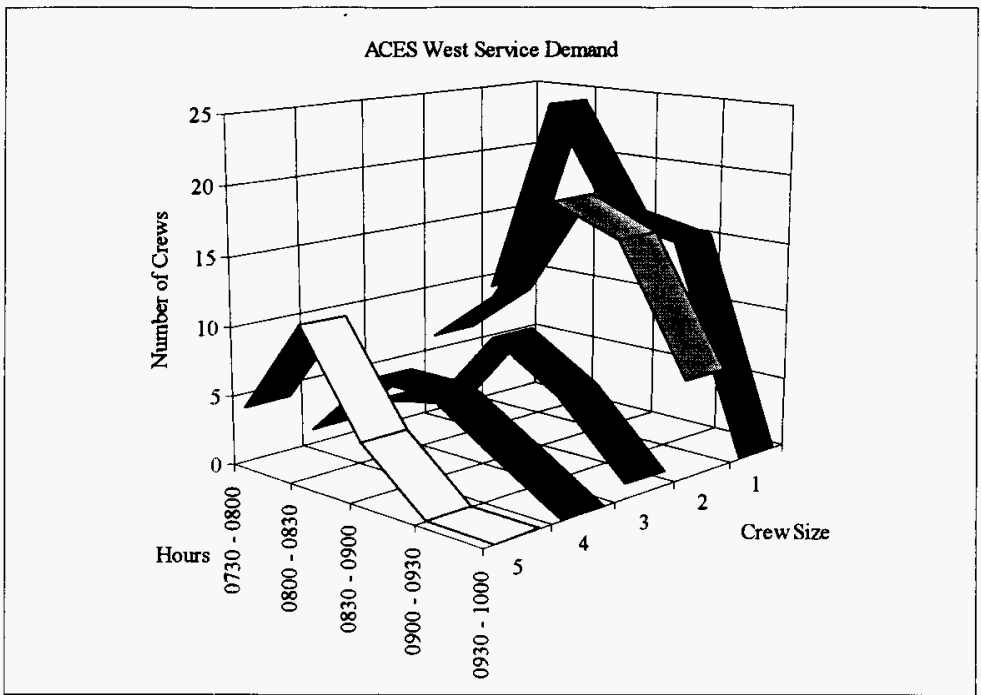

Figure 3 Service Demands vs Time Period and Crew Size 


\section{Key Control Assignment}

Several of the major tank farms do not require keys for access, as they have operations personnel manning the entrance. In this situation, workers travel from one of the ACES stations directly to the change trailer (entrance to a tank farm complex) or gate. For other areas, keys are used to unlock the entrance change trailer or gate. Keys are obtained from key control stations in the appropriate area. In addition, there may be keys required for gates in various sections of a major work area.

When a key is required, similar steps as described in the ACES authorization process are repeated. The PIC or other designate proceeds to the key control station while the remaining workers are generally idle. ${ }^{25}$ The PIC conveys work location information to the key control clerk, signs key log, receives key and returns to the crew. Problems in running out of keys can cause delays for the crew. An individual obtaining a key can encounter a similar problem.

Table 3 provides a synopsis of the functions, associated time and costs of the process step.

\begin{tabular}{|c|c|c|c|c|c|c|c|}
\hline \multirow[t]{2}{*}{ Process Step: } & \multicolumn{2}{|c|}{$\begin{array}{l}\text { Key Control } \\
\text { Assignment }\end{array}$} & & & \multicolumn{3}{|r|}{ Table 3} \\
\hline & Op Time & $\begin{array}{l}\text { Idle } \\
\text { Time }\end{array}$ & $\begin{array}{l}\text { Total } \\
\text { Time }\end{array}$ & Rate & $\begin{array}{l}\text { Cost' } \\
\text { Incident }\end{array}$ & $\begin{array}{l}\text { LifeCycle } \\
\text { Cost }(7 \mathrm{yr})\end{array}$ & comments \\
\hline $\begin{array}{l}\text { Travel To \& From } \\
\text { Key Control Station }\end{array}$ & $\begin{array}{l}0.2 \mathrm{hrs} \\
\text { /PIC }^{26}\end{array}$ & NA & $\begin{array}{l}0.2 \mathrm{hrs} \\
\text { PIC }\end{array}$ & $\begin{array}{l}\$ 58.39 \\
\mathrm{hur}^{27}\end{array}$ & $\$ 11.68$ & $\$ 804 k^{24}$ & $\begin{array}{l}\text { Keys needed to be obtained } 189 \text { times } \\
\text { (out of 236) during the review period. }\end{array}$ \\
\hline Wait In Line & NA & $\begin{array}{l}0.1 \mathrm{hrs} \\
\text { /PIC }\end{array}$ & $\begin{array}{l}0.1 \mathrm{hrs} \\
\text { PIC }\end{array}$ & $\begin{array}{l}\$ 58.39 \\
\mathrm{Mr}\end{array}$ & $\$ 5.84$ & $\$ 402 k^{2 \prime \prime}$ & $\begin{array}{l}\text { Average time PIC waits in line for other } \\
\text { crews to get their keys. Peak times have } \\
\text { delay. }\end{array}$ \\
\hline Key Checkout & $\begin{array}{l}0.05 \mathrm{hrs} \\
\text { PIC }\end{array}$ & NA & $\begin{array}{l}0.05 \mathrm{hrs} \\
\text { PIC }\end{array}$ & $\begin{array}{l}\$ 58.39 \\
\mathrm{hr}\end{array}$ & $\$ 2.92$ & $\$ 201 k^{21}$ & $\begin{array}{l}\text { Average time PIC actually spends } \\
\text { interacting with key control clerk. }\end{array}$ \\
\hline Crew Waits & NA & $\begin{array}{l}2.45 \mathrm{hrs} \\
/ \mathrm{crew}^{20}\end{array}$ & $\begin{array}{l}2.45 \mathrm{hrs} \\
\text { /crew }\end{array}$ & $\begin{array}{l}\$ 46.25 \\
\mathrm{hr} \mathrm{r}^{* 0}\end{array}$ & $\$ 113.31$ & $\$ 3,093 \mathbf{k}^{31}$ & $\begin{array}{l}\text { Average time crew spends waiting for } \\
\text { PIC to obtain key. }\end{array}$ \\
\hline $\begin{array}{l}\text { Resolve } \\
\text { Declination }\end{array}$ & NA & NA & NA & $\mathrm{NA}$ & NA & NA & $\begin{array}{l}\text { Delays due to improper paperwork or } \\
\text { lack of keys. }\end{array}$ \\
\hline
\end{tabular}

It should be noted this description is only typical. There are reported differences. For example, some PIC's obtain keys prior to remaining crew arrival to elininate delays. The study was not able to quantitatively determine differences.

Composite average between various ACES stations and key control locations of 6 minutes each direction. For 200 West area, they are in separate buildings that are adjacent (1 minute walk each direction.) For four out of five ACES stations in 200 East area, travel is required (average 10 minutes each direction)

Rate for PIC (typically exempt) plus org. overhead (22\%), G\&A (13\%) and CSP (2\%)

Calculated by Cost\$/incident x 189 incidents/wk $\times 52$ wks/yr $\times 7$ yrs. All costs are in FY 1996 dollars. Life cycle is for seven years, nonescalated.

Calculated as 0.35 hrs $\times 7$ idle crew members $=2.45$ hrs.

Composite rate of all participants including supervision, engineering, HPT \& craft as applicable, plus org. overhead (22\%), G\&A (13\%) and $\operatorname{CSP}(2 \%)$. ICF KH rates are higher.

Calculated by CostS/incident $\times 75$ incidents/wk $\times 52$ wks $/ y r \times 7$ yrs. The 75 incidents/wk reflects an assumption that a crew waits $40 \%$ of the time keys are required, based on interviews. All costs are in FY 1996 dollars. Life cycle is for seven years, non-escalated.

32 Time and cost were not quantifiable within this study (no case observed) but interviews suggested that resolving key problems could occasionally require substantial time, during which an entire crew may be idle. 


\section{Noted Problems}

- Delays due to insufficient keys may cause substantial delay costs for a large crew.

- Delays due to unavailability of the key control clerk may cause substantial delay costs for a large crew. 


\section{Enter Controlled Work Area}

When the crew arrives at a controlled work area change trailer entrance or gate, the PIC opens the trailer and lets in each crew worker. Once inside, each worker enters their identification, the time and date of entrance, and the dosimeter identification in a log. The vehicle entrance gate is opened, if required. Crew workers change into any protective clothing and gear and proceed on to the work area.

Table 4 provides a synopsis of the functions, associated time and costs of the process step.

\begin{tabular}{|c|c|c|c|c|c|c|c|}
\hline \multirow{2}{*}{$\begin{array}{l}\text { Process Step: } \\
\text { Function }\end{array}$} & \multicolumn{2}{|c|}{$\begin{array}{l}\text { Enter Controlled } \\
\text { Work Area }\end{array}$} & \multirow[b]{2}{*}{$\begin{array}{l}\text { Total } \\
\text { Time }\end{array}$} & \multirow[b]{2}{*}{ Rate } & \multirow[b]{2}{*}{$\begin{array}{l}\text { Cost } \\
\text { Incident }\end{array}$} & \multicolumn{2}{|r|}{ Table 4} \\
\hline & Op Time & \begin{tabular}{|l} 
Idle \\
Time
\end{tabular} & & & & $\begin{array}{l}\text { LifeCycle } \\
\text { Cost }(7 \mathrm{yr})^{\prime \prime}\end{array}$ & comments \\
\hline $\begin{array}{l}\text { Travel To } \\
\text { Controlled Work } \\
\text { Area }\end{array}$ & $\begin{array}{l}0.8 \mathrm{hrs} \\
/ \text { crew }\end{array}$ & NA & $\begin{array}{l}0.8 \mathrm{hrs} \\
\text { /crew }\end{array}$ & $\begin{array}{l}\text { S46.25 } \\
\text { hrr }\end{array}$ & $\$ 37.00$ & $\mathbf{\$ 3 , 2 0 5 k}$ & \\
\hline Log Entries & $\begin{array}{l}0.067 \\
\text { hrs /crew }\end{array}$ & $\begin{array}{l}0.47 \mathrm{hrs} \\
\text { /crew }\end{array}$ & $\begin{array}{l}0.54 \mathrm{hrs} \\
\text { /erew }\end{array}$ & $\begin{array}{l}\$ 46.25 \\
\mathrm{hr}\end{array}$ & $\$ 24.82$ & $\$ 2,150 \mathrm{k}$ & \\
\hline $\begin{array}{l}\text { Change Into } \\
\text { Protective Clothing }\end{array}$ & $\begin{array}{l}1.6 \mathrm{hrs} \\
\text { /crew }\end{array}$ & NA & $\begin{array}{l}1.6 \mathrm{hrs} \\
\text { /erew }\end{array}$ & $\begin{array}{l}\$ 46.25 \\
\mathrm{hr}\end{array}$ & $\$ 74.00$ & $\$ 6.411 \mathrm{k}$ & \\
\hline
\end{tabular}

\section{Noted Problems}

- Entry/Exit $\log$ book is not always accurate (workers forget to $\log$ in.) This is a problem for evacuation accountability and for accurate entry records.

- Entry/Exit log books are not being maintained for tank farms which have been down-posted to underground radioactive material areas. Entry/exit records are generally desirable to demonstrate appropriate facility management to regulators.

- Continuous manning of major tank farms consumes available manpower and funds. ${ }^{35}$ 


\section{Perform Work W $^{36}$}

Once inside the work area, the workers perform the activities of the work package.

\section{Noted Problems}

None noted.

\section{Exit Controlled Work Area}

At the end of the task or work day, or at a break for lunch, the crew returns to the change trailer to remove protective gear and change clothing. If the work has been in an area of possible radiological contamination, each crew member is surveyed by an HPT, or completes a radiological self-survey, and signs a checkout log book. Any hand items carried into the controlled area require a HPT to survey and release upon exit.

Table 5 provides a synopsis of the functions, associated time and costs of the process step.

\begin{tabular}{|c|c|c|c|c|c|c|c|}
\hline \multirow{2}{*}{$\begin{array}{l}\text { Process Step: } \\
\text { Function }\end{array}$} & \multicolumn{2}{|c|}{$\begin{array}{l}\text { Exit Controlled } \\
\text { Work Area }\end{array}$} & & & \multicolumn{3}{|r|}{ Table 5} \\
\hline & Op Time & $\begin{array}{l}\text { Idle } \\
\text { Time }\end{array}$ & $\begin{array}{l}\text { Total } \\
\text { Time }\end{array}$ & Rate & $\begin{array}{l}\text { Cost/ } \\
\text { Incident }\end{array}$ & $\begin{array}{l}\text { LifeCycle } \\
\text { Cost }(7 \mathrm{yr})^{*}\end{array}$ & comments \\
\hline Radiological survey & $\begin{array}{l}0.8 \mathrm{hrs} \\
\text { /crew }\end{array}$ & $N A^{3 n}$ & $\begin{array}{l}0.8 \mathrm{hrs} \\
/ \mathrm{crew}\end{array}$ & $\begin{array}{l}\$ 46.25 \\
\mathrm{hr}\end{array}$ & $\$ 37.00$ & $\$ 3,205 k$ & \\
\hline Log entries & $\begin{array}{l}0.067 \\
\text { hrs /crew }\end{array}$ & $\begin{array}{l}0.47 \mathrm{hrs} \\
\text { /crew }\end{array}$ & $\begin{array}{l}0.54 \text { hrs } \\
\text { /crew }\end{array}$ & $\begin{array}{l}\$ 46.25 \\
\mathrm{hr}\end{array}$ & $\$ 24.82$ & $\$ 2,150 \mathrm{k}$ & \\
\hline $\begin{array}{l}\text { Change out of } \\
\text { protective clothing }\end{array}$ & $\begin{array}{l}1.6 \mathrm{hrs} \\
\text { /orew }\end{array}$ & 0 & $\begin{array}{l}1.6 \mathrm{hrs} \\
/ \mathrm{crew}\end{array}$ & $\begin{array}{l}\$ 46.25 \\
\mathrm{hr}\end{array}$ & $\$ 74.00$ & $\$ 6,411 \mathrm{k}$ & \\
\hline $\begin{array}{l}\text { Survey equipment } \\
\text { and/or vehicles } \\
\text { througi gate. }\end{array}$ & $\begin{array}{l}\text { Not } \\
\text { Avail. }\end{array}$ & $\begin{array}{l}\text { Not } \\
\text { Avail. }\end{array}$ & $\begin{array}{l}\text { Not } \\
\text { Avail. }\end{array}$ & $\begin{array}{l}\text { Not } \\
\text { Avail. }\end{array}$ & $\begin{array}{l}\text { Not } \\
\text { Avail. }\end{array}$ & $\begin{array}{l}\text { Not } \\
\text { Avail. }\end{array}$ & $\begin{array}{l}\text { There is a time impact, but no } \\
\text { quantitative analysis is available for this } \\
\text { study. }\end{array}$ \\
\hline & & & & & & & \\
\hline
\end{tabular}

\section{Noted Problems}

- Delays are experienced when HPTs are not available immediately for the radiological survey. 


\section{Return Key and Dosimetry}

The crew travels back to the key control station to the return key. They travel back to the ACES station to check in the dosimeters, and finally back to their starting point.

Table 6 provides a synopsis of the functions, associated time and costs of the process step.

\begin{tabular}{|c|c|c|c|c|c|c|c|}
\hline \multicolumn{3}{|l|}{ Process Step: } & \multirow[b]{2}{*}{$\begin{array}{l}\text { Total } \\
\text { Time }\end{array}$} & \multirow[b]{2}{*}{ Rate } & \multirow[b]{2}{*}{$\begin{array}{l}\text { Cost/ } \\
\text { Incident }\end{array}$} & \multicolumn{2}{|r|}{ Table 6} \\
\hline Function & Op Time & $\begin{array}{l}\text { Idle } \\
\text { Time }\end{array}$ & & & & $\begin{array}{l}\text { LifeCycle } \\
\text { Cost }(7 \mathrm{yr})^{11}\end{array}$ & comments \\
\hline $\begin{array}{l}\text { Travel To ACES \& Key } \\
\text { Control Stations }\end{array}$ & $\begin{array}{l}0.8 \mathrm{hrs} \\
/ \mathrm{crew}\end{array}$ & & $\begin{array}{l}0.8 \mathrm{hrs} \\
/ \mathrm{crew}\end{array}$ & $\begin{array}{l}\$ 46.25 \\
\mathrm{hr}\end{array}$ & $\mathbf{S 3 7 . 0 0}$ & $\$ 3.205 k$ & \\
\hline Return Dosimeters & $\begin{array}{l}0.1 \mathrm{hrs} \\
\text { /crew }\end{array}$ & $\begin{array}{l}0.7 \mathrm{hrs} \\
\text { /crew }\end{array}$ & $\begin{array}{l}0.8 \mathrm{hrs} \\
\text { /crew }\end{array}$ & $\$ 46.25$ & $\$ 37.00$ & $\mathbf{\$ 3 , 2 0 5 k}$ & $\begin{array}{l}\text { Quick return (not waiting while } \\
\text { they are checked in) by one persor }\end{array}$ \\
\hline Return Keys & $\begin{array}{l}.1 \mathrm{hrs} \\
\text { /crew }\end{array}$ & $\begin{array}{l}0.7 \mathrm{hrs} \\
/ \mathrm{crew}^{\prime 2}\end{array}$ & $\begin{array}{l}0.8 \mathrm{hrs} \\
\text { /crew }\end{array}$ & $\$ 46.25$ & $\$ 37.00$ & $\$ 3,20 \$ k$ & Quick retum by one person \\
\hline $\begin{array}{l}\text { Return to assigmment } \\
\text { area }\end{array}$ & $\begin{array}{l}1.33 \mathrm{hrs} \\
\text { /crew }\end{array}$ & $\begin{array}{l}0.4 \mathrm{hrs} \\
\text { /crew }\end{array}$ & $\begin{array}{l}1.73 \mathrm{hrs} \\
\text { /crew }\end{array}$ & $\$ 46.25$ & $\$ 80.00$ & $\$ 6,931 \mathrm{k}$ & $\begin{array}{l}\text { Idle time includes time to gather } \\
\text { and load crew in vehicle, } \\
\text { occasional fueling of vehicle. }\end{array}$ \\
\hline & & & & & & & \\
\hline
\end{tabular}

\section{Noted Problems}

None noted.

\section{Post-Job Activity ${ }^{43}$}

The crew regroups and meets to discuss the activities of the day. and CSP (2\%). ICF KH rates are higher.

41 Calculated by CostS/incident $\times 238$ incidents/wk x 52 wks/yr $\times 7$ yrs. All costs are in FY 1996 dollars. LifeCycle is for seven (7) years, non-escalated.

42 There was disagreement between those interviewed as to the idle time of the crew when keys were being returned. The entire crew does not return the keys. However, the crew typically must stop work 6 minutes eariier to exit the worksite so lockup can oceur and the key returned, or is otherwise unproductive (camnot start the next job until PIC returns.) 


\section{DESCRIPTION OF ALTERNATIVES}

\section{A. OVERVIEW}

There are many mixes of alternatives that would provide a significant savings of personnel time and energy over the current process of validating the qualifications of personnel who perform work in hazardous and/or radiological work areas. The alternatives are limited to those most likely to be implementable.

\section{Alternative 0 Do Nothing (existing process baseline)}

Maintain the existing systems and procedures. This provides a baseline for comparison against the other alternatives. It is discussed in Section III.B.

\section{Alternative 1 Administrative Improvements To Current Process}

Provide several discrete and individual administrative improvements to the existing process. The improvements do not require substantial equipment purchases or software modifications. Any or all may be implemented. With full implementation, the net life cycle savings over 7 years is estimated to exceed \$12.9 million. See section IV.B.1, page 19 for additional information.

1.a Consolidate/Relocate ACES and Key Control Stations Eliminate the separate facilities where possible. Keys, when required, would be issued after ACES approval by the ACES operator. Reorganize the physical layout of the ACES station to improve flow.

1.b Prejob Qualification Verification

Improve, then use the prejob qualification verification capabilities within ACES. Requires indoctrination and training of planners, supervisors, and PICS; and minor modifications to the ACES.

1.c Formal Training for ACES Users, Including TWRS Planners, Supervisors, and/or PICS Provide formal training on the ACES. This will improve the efficiency of ACES station operators, and provide needed information and incentive for planners, PICS, and supervisors.

\section{Alternative 2 Redesign Current Process/ACES}

Provide several discrete and individual technical and administrative improvements to the existing process and the ACES. These would require equipment purchases, software modernization, and significant administrative process change. Any or all may be implemented. With full implementation, the net life cycle savings over 7 years is estimated to exceed $\$ 32.8$ million. See section IV.B.2, page 27 for additional information.

\section{2.a Decentralize/Simplify ACES}

Place simplified ACES interface stations in assignment and/or briefing areas for the use of team leads or PICS. Team leads, PICS, or other supervision would self-clear teams and individuals. Interface to ACES would be simplified to the qualification task using bar code or other machine readable technologies. Two central (albeit reduced) ACES stations would be maintained for special circumstances.

2.b Decentralize Key Control

Eliminate most centralized key distribution. Distribute keys to the autonomous work groups (as defined in the TWRS Ops Reengineering Plan.) Team leads, PICS, or other supervisors would check out keys as part of the prejob briefing. Centralized key distribution would continue only where necessary (e.g., external workers.) 
2.c Redesign Training Records Information (TRI) System

Redesign the TRI system to match Site enterprise-wide objectives. Provide near-real time updates of training completion records. Provide automated updates to the ACES.

\section{2.d Implement Electronic Dosimetry}

Replace current hand-entered pocket dosimetry with electronic versions. Team leads, PICS, or other supervisors would issue electronic pocket dosimetry each day through the simplified ACES interface stations. The simplified ACES station would also be used to check back in each dosimeter and automatically update record.

\section{Alternative 3 Phased Replacement with Automated Site Entry System}

TWRS operations representatives have expressed a strong desire for an alternative that provides a multi-year, phased approach that considers the need for immediate action, but is realistic to budget cycles and funding constraints. Alternative 3 is simply a phased approach of the first two alternatives, plus development of a site entrance control system. With full implementation, the net life cycle savings over 7 years is estimated to exceed \$47.8 million.

\subsection{Implement Alternative 1 Above}

Implement much of Alternative 1 in fiscal year 1996, with existing expense funding.

\subsection{Implement Alternative 2 Above}

Immediately budget for alternative 2 for implementation in fiscal year 1997. The majority of funding would be expense, with limited capital equipment not related to construction (CENRTC) needs.

\subsection{Implement Automated Site Entry Pilot/Prototype-- Single Farm}

Develop and pilot a simplified ACES interface system for one tank farm entry (change) trailer. System would provide totally automated qualification validation, dosimetry issuance and collection, and keyless entry/exit on an individual and team basis. Immediately budget for this altemative for implementation in fiscal year 1997.

\subsection{Implement Automated Site Entry - All Appropriate Locations}

Implement the pilot system described in alternative 3.3 in all frequently used tank farms. ${ }^{44}$

See section IV.B.3, page 42 for additional information.

\section{Replace with Smart Card Site Entry System}

Replace the entire ACES with the very latest in technology--a Smart Card system. Smart Cards are actual computers (processor, memory, and input/output) embedded in a credit card or security badge. The Smart Card would hold all qualification information for an individual. Unlike magnetic stripe (e.g., credit cards), Smart Cards provide extremely high security for the information they contain and their ability to validate the user. 
When an individual takes a class, goes for a mask fit, reads an RWP, or gets a physical, the Smart Card would be used to securely identify the individual, then the results would be recorded. Necessarily, there would be a Smart Card interface terminal at each of these locations. At each farm/zone entrance would be a Smart Card interface terminal, with the entrance requirements (including radiation exposure expectations) for that area. The individual inserts the Smart Card, enters a Personal Identification Number (PIN), and enters the RWP working under (if required). The SmartCard interface compares the requirements for entry into the area it is guarding with the individual's qualifications. It retrieves the individual's current exposure record, adds the expected exposure for the area, and provides a go/no go decision.

With full implementation, the net life cycle savings over 7 years is estimated to exceed $\$ 40.8$ million. See section IV.B.4, page 48 for additional information.

\section{$5 \quad$ Purchase and Implement Commercial System (Replace Existing)}

Create a specification and competitively procure a commercial system. There are several vendors that sell access qualification and control systems to the nuclear industry. With full implementation, the net life cycle savings over 7 years is estimated to exceed $\$ 39.5$ million. See section IV.B.5, page 55 for additional information. 


\section{B. ANALYSIS OF ALTERNATIVES}

\section{Administrative Improvements To Current Process}

Table 7 is a summary of the sub-alternatives for alternative 1 . Details of each sub-alternative follow.

\begin{tabular}{|c|c|c|c|c|c|}
\hline $\begin{array}{l}\text { Table } 7 \\
\text { Alternative Description }\end{array}$ & $\begin{array}{l}\text { Cost of } \\
\text { Implementation }\end{array}$ & $\begin{array}{l}\text { Net Annual } \\
\text { Reoccurring } \\
\text { Coets }\end{array}$ & $\begin{array}{l}\text { 1st Year } \\
\text { Savingess }\end{array}$ & $\begin{array}{l}7 \text { Yr LifeCycle } \\
\text { Sevings" }\end{array}$ & $\begin{array}{l}\text { LCS/C } \\
\text { Ration }\end{array}$ \\
\hline 1.a Consolidate/Relocate ACES and Key Control Stations & $\$ 18.5 k$ & No Change & \$596k & $\$ 4,281 \mathrm{k}$ & 230 \\
\hline 1.b Prejob Qualification Verification & \$11sk & $\$ 2.5 k$ & $\$ 1,146 \mathrm{k}$ & \$ $8,689 \mathrm{k}$ & 75 \\
\hline 1.c Formal Training For ACES Users & $\$ 62 k$ & s5k & Unknnown & Unknown & Unknown \\
\hline Total for Administrative Improvements to Current Process & $\$ 196 k$ & \$7.5k & $\$ 1,742 \mathrm{k}$ & $\$ 12,970 \mathrm{k}$ & 66 \\
\hline
\end{tabular}

\section{a. Consolidate/Relocate ACES, Key Control and Radio Checkout Stations}

The ACES station, key control and radio checkout could be consolidated in the 272 WA (200-West Area) and $272 \mathrm{AW}$ (200-East Area.) The purpose would be to reduce travel and worker idle time when a key and/or radio is retrieved. See Section III.B.4, page 11. At this time, ACES and key control stations are in one building in 200-East Area, and in separate, adjacent buildings in 200-West Area. A controlled work area entry key, if needed, would be processed immediately after ACES approval. Personnel used primarily for checking out keys (key control clerk), although not totally eliminated, would be more available for alternative tasks. In addition, two-way radios could also be checked out.

This alternative calls for reorganization of the physical layout of the ACES stations in 272WA and 272AW. Personnel going through the consolidated ACES and key control station would follow a clearly designated line-in/line-out flow path for easy access.

Consideration should be given to adding a second ACES terminal into the layout and staffing the terminal during peak hours (8-9:00 a.m. weekdays.) An additional terminal would substantially reduce crew idle time.

\section{Advantages}

- Reduces waiting in line/idle time of both the person obtaining a key and the remainder of the crew waiting to get to work. By consolidating ACES station and key control, the additional travel from the ACES station to the key control station and wait time in a key control station would be eliminated for a majority of key needs.

- Provide easy access. By designating a clear throughput access and removing traffic/noise from the ACES station, the waiting time will be reduced.

- Reduces manned station operation costs at the key control stations.

Calculated as: 1 Year Cost Savings - Cost of Implementation

Calculaled As: Lifecycle Saving (7 Yr) - Impiementation Costs - Lifecyele Reoccurring Costs

Ratio of LifeCycle Costs / Implementation Costs 
- Requires workers to verify access entry at the ACES station before obtaining a key to enter work area. Workers cannot receive a key without being verified at the ACES station first.

- The ergonomic layout of the ACES station for the HPT operator would be improved to enhance operator throughput and lessen chances of on-the-job injury from constant usage (e.g., repetitive motion problems.) This would improve the flow of personnel and lower idle time through the entire process.

\section{Implementation Considerations}

- Implementation cost involved for design and construction of new layout, and moving office equipment.

- Increases workload on ACES operators (HPTs.) Although there is a net improvement in work hours required for the process, an additional time and responsibility burden is placed on the HPT.

- Implementation may affect current labor agreements (not contractual) and require negotiations.

\section{Implementation Steps/Schedule}

Table 8 is a summarization of the tasks required to implement this alternative.

\begin{tabular}{|c|c|c|c|c|c|c|}
\hline \multicolumn{3}{|c|}{ Consolidate/Relocate ACES and Key Control Stations } & \multicolumn{4}{|c|}{ Table 8} \\
\hline Subtask Description & Duration & Effort & Rate & Labor Cost & Mtl Cost & Total Cost \\
\hline Project Control & & $24 \mathrm{hrs}$ & $\$ 65.49$ & $\$ 1.6 \mathrm{k}$ & & $\$ 1.6 \mathrm{k}$ \\
\hline $\begin{array}{l}\text { Evaluate ACES Station for Ergonomics } \\
\text { (HEHF) }\end{array}$ & 5 days & $8 \mathrm{hrs}$ & so 4 & & & so \\
\hline Design Layout of Stations & 5 days & 40 hrs & $\$ 68.20^{49}$ & $\$ 2.8 \mathrm{k}$ & & $\$ 2.8 \mathrm{k}$ \\
\hline Construct Stations & 8 days & $64 \mathrm{hrs}$ & $\$ 44.56^{50}$ & $\$ 2.9 \mathrm{k}$ & $\$ 1.5 \mathrm{k}$ & $\$ 4.4 \mathrm{~K}$ \\
\hline Move/Procure Equipment ${ }^{51}$ & 3 days & $8 \mathrm{hrs}$ & $\$ 44.56$ & $\$ 0.4 k$ & $\$ 0.6 \mathrm{k}$ & $\$ 1.0 \mathrm{k}$ \\
\hline $\begin{array}{l}\text { Program Bar code Wedge/ Setup } \\
\text { Additional Computer }\end{array}$ & 5 days & 40 hrs & $\$ 81.84$ & $\$ 3.3 k$ & & $\$ 3.3 \mathrm{k}$ \\
\hline Modify Procedures \& Documents & 36 days & $40 \mathrm{hrs}$ & $\$ 69.00$ & $\$ 2.8 \mathrm{k}$ & & $\$ 2.8 \mathrm{k}$ \\
\hline Training/ Turnover & 10 days & 32 hrs & $\$ 81.84$ & $\$ 2.6 \mathrm{k}$ & & $\$ 2.6 \mathrm{k}$ \\
\hline Total & 36 days & $256 \mathrm{hrs}$ & & $\$ 16.4 \mathrm{k}$ & $\$ 2.1 \mathrm{k}$ & $\$ 18.5 \mathrm{k}$ \\
\hline
\end{tabular}

HEHF provides assessments at no cost. 


\section{Reoccurring Costs}

Sub alternative l.a does not have identified reoccurring costs.

\section{Cost Savings}

Table 9 summarizes the process steps that would be effected by the alternative and the cost impact anticipated. Table 10 reconciles the cost of implementation with the anticipated cost savings.

\begin{tabular}{|c|c|c|c|c|c|c|}
\hline \multicolumn{2}{|l|}{ Consolidate/Relocate ACES and Key Control Stations } & \multicolumn{5}{|c|}{ Table 9} \\
\hline \multicolumn{2}{|l|}{ Process Step/Function To Modify/Eliminate } & $\begin{array}{l}\text { Cost / } \\
\text { Incident }\end{array}$ & $\begin{array}{l}1 \text { Year Cost } \\
\text { Savings }\end{array}$ & $\begin{array}{l}\text { LifeCycle } \\
\text { Svge }(7 \mathrm{yr})\end{array}$ & \multicolumn{2}{|l|}{ Comments } \\
\hline \multicolumn{2}{|l|}{$\begin{array}{l}\text { Key Control Assignment: (see page 11) } \\
\text { Travel To \& From Key Control Station }\end{array}$} & $\$ 11.68$ & $\$ 115 k$ & $\$ 804 k$ & & \\
\hline \multicolumn{2}{|l|}{ Wait In Line } & $\$ 5.84$ & \$57k & $\$ 402 k$ & \multicolumn{2}{|c|}{$\begin{array}{l}\text { Eliminated as part of combined wait at } \\
\text { ACES station. }\end{array}$} \\
\hline \multicolumn{2}{|l|}{ Key Checkout } & $\$ 2.92$ & NA & NA & \multicolumn{2}{|c|}{$\begin{array}{l}\text { No savings, as keys are still checked } \\
\text { out, just at different place. }\end{array}$} \\
\hline \multicolumn{2}{|l|}{ Crew Waits } & $\$ 133.31$ & $\$ 442 k$ & $\$ 3,093 k$ & \multicolumn{2}{|c|}{ Eliminated in $40 \%$ of cases. } \\
\hline \multicolumn{2}{|l|}{ Resolve Declination } & NA & NA & NA & \multicolumn{2}{|c|}{ Still required, no savings. } \\
\hline \multicolumn{2}{|l|}{ ACES Checkout } & $\begin{array}{l}\text { Not } \\
\text { Avail. }\end{array}$ & $\begin{array}{l}\text { Not } \\
\text { Avail. }\end{array}$ & $\begin{array}{l}\text { Not } \\
\text { Avail. }\end{array}$ & \multicolumn{2}{|c|}{$\begin{array}{l}\text { Ergonomic streamlining of the } \\
\text { combined station will improve } \\
\text { throughput and reduce delays, but no } \\
\text { quantitative savings are available. }\end{array}$} \\
\hline & Total & $\$ 153.75$ & $\$ 614 k$ & $\$ 4,299 k$ & & \\
\hline $\begin{array}{l}\text { Table } 10 \\
\text { Alternative Description }\end{array}$ & $\begin{array}{l}\text { Cost o } \\
\text { Implen }\end{array}$ & nentation & $\begin{array}{l}\text { Net Annual } \\
\text { Reoccurring } \\
\text { Costs }\end{array}$ & $\begin{array}{l}\text { 1st Year } \\
\text { Savings: }\end{array}$ & $\begin{array}{l}7 \text { Yr LifeCycle } \\
\text { Savings }\end{array}$ & $\begin{array}{l}\text { LCS/IC } \\
\text { Ration }\end{array}$ \\
\hline 1.2 ACES and Key Control Stations & $\$ 18.5 \mathrm{k}$ & & No Change & $\$ 596 \mathrm{k}$ & $\$ 4,281 \mathrm{k}$ & 230 \\
\hline
\end{tabular}




\section{b. Prejob Qualification Verification}

The ACES has a seldom used function to verify worker qualification at the prejob planning stage. Interviews indicate that few supervisors, planners, or PICs know of the availability of the function. In addition, most of those interviewed were under the false assumption that ACES was not readily available except at the ACES stations, receiving accounts would be difficult, and/or the system was too complicated to use. ACES is available to anyone with a need, and obtaining an account is neither difficult or time consuming. A user, without training, likely would be overwhelmed. A simple, 1-hour briefing formatted specifically for the task of prejob qualification verification and targeted toward the planner, PIC, or supervisor would provide all of the information necessary to perform the function and to substantially reduce the declinations occurring at the ACES stations. The current ACES user interface is not very user friendly, but it is workable for this singular task.

It is also recommended that the ACES software be modified to store prequalification packages initiated by the planner or PIC. These packages would prequalify an entire work team for entry on a range of dates. A printed form would be provided with the prequalification information and the prequalification package ID. The planner or PIC could retrieve and edit the package as needed (e.g., a team member calls in sick.) When the date of work initiation arrives, the team would travel to the ACES station for final qualification verification and pocket dosimetry. Instead of qualifying each individual of the team, the team lead would provide the prequalification package ID to the ACES station operator. The ACES station operator would visually verify each person on the list, enter the associated pocket dosimetry ID (through the station bar code keyboard wedge), and the entire team verification is complete. It is estimated that this would reduce the combined process and idle time for a team by 40 percent. It does require additional effort by the planner, PIC, or supervisor. ${ }^{55}$

\section{Advantages}

- Workers would be prequalified prior to final verification at the ACES station. Incidences of declination (rejection) would be reduced substantially.

- Assignment supervisors, planners, and/or PICs would have a clearer understanding of the qualification status of workers and could make better, more cost-effective assignments based on this knowledge. Less reactionary rescheduling and last minute shuffling of personnel would occur, improving productivity.

\section{Implementation Considerations}

- May require improved computer workstations for some planners, PIC's, and supervisors.

- Supervisors and PICs are currently very busy and may consider this an additional task. 


\section{Implementation Steps/Schedule}

Table 11 is a summarization of the tasks required to implement this alternative.

\begin{tabular}{|l|l|l|l|l|l|}
\hline \multicolumn{2}{|l|}{ Prejob Qualification Verification } & \multicolumn{3}{c}{ Table 11 } \\
\hline Subtask Description & Duration & Effort & Rate & Labor Cost & Total Cost \\
\hline \hline Project Control & 6 months & $136 \mathrm{hrs}$ & $\$ 65.49$ & $\$ 8.9 \mathrm{k}$ & $\$ 8.9 \mathrm{k}$ \\
\hline $\begin{array}{l}\text { Add Pre-Qualification Enhancements To } \\
\text { Existing ACES }\end{array}$ & 4 months & $910 \mathrm{hrs}$ & $\$ 81.84^{\text {s6 }}$ & $\$ 75 \mathrm{k}$ & $\$ 75 \mathrm{k}$ \\
\hline $\begin{array}{l}\text { Develop Training Package-PIC's and } \\
\text { ACES Station Operators }\end{array}$ & 1 month & $150 \mathrm{hrs}$ & $\$ 69.00^{57}$ & $\$ 10.4 \mathrm{k}$ & $\$ 10.4 \mathrm{k}$ \\
\hline $\begin{array}{l}\text { Perform Training At Site-PIC's and } \\
\text { ACES Station Operators }\end{array}$ & 2 months & $300 \mathrm{hrs}$ & $\$ 69.00$ & $\$ 20.7 \mathrm{k}$ & $\$ 20.7 \mathrm{k}$ \\
\hline \hline
\end{tabular}

\section{Reoccurring Costs}

Sub altemative 1.b would require provision of the training class for new or reassigned personnel and for those desiring a refresher for each year of the life cycle. This is estimated at 12 classes per year, 3 hours per class (including instructor preparation and travel.) Cost per year would be $\$ 2.5 \mathrm{k}$. A seven year Life cycle cost would be $\$ 15 k^{58}$. 


\section{Cost Savings}

Table 12 summarizes the process steps that would be effected by the alternative and the cost impact anticipated. Table 13 reconciles the cost of implementation with the anticipated cost savings.

\begin{tabular}{|c|c|c|c|c|c|c|}
\hline \multicolumn{2}{|l|}{ Prejob Qualification Verification } & \multicolumn{5}{|c|}{ Table 12} \\
\hline Process Step/Function To Modify/Eliminate & & $\begin{array}{l}\text { Cost / } \\
\text { Incident }\end{array}$ & $\begin{array}{l}1 \text { Year Cost } \\
\text { Savings }\end{array}$ & $\begin{array}{l}\text { LifeCycle } \\
\text { Svgs (7 yr) }\end{array}$ & Comments & \\
\hline $\begin{array}{l}\text { ACES Checkout: (see page 7) } \\
\text { Travel to ACES Station }\end{array}$ & & NA & NA & NA & $\begin{array}{l}\text { No savings, travel to } \\
\text { required. }\end{array}$ & CES station still \\
\hline Wait In Line For Other Crews & & $\$ 61.50$ & $\$ 305 k^{60}$ & $\$ 2,131 k^{11}$ & Reduces wait by $40 \%$ & \\
\hline ACES Qualification Checkout & & $\$ 148.00$ & $\$ 733 k^{60}$ & $\$ 5,129 k^{61}$ & Reduces checkout tim & s by $40 \%$ \\
\hline Checkout Pocket dosimeter & & NA & NA & NA & No savings, still requi & \\
\hline Resolve Major Declination & & $\$ 592.00$ & $\$ 197 \mathrm{k}^{42}$ & $\$ 1,379 k^{\bullet}$ & Reduces major declin & tions by $40 \%$ \\
\hline Resolve Minor Declination & & $\$ 247.00$ & $\$ 26 k^{e n}$ & $\$ 180 k^{\text {es }}$ & Reduces minor declin & tions by $40 \%$ \\
\hline & Total & & $\$ 1,261 k$ & \$ 8,819k & & \\
\hline $\begin{array}{l}\text { Table } 13 \\
\text { Altemative Description }\end{array}$ & $\begin{array}{l}\text { Cost } \\
\text { Impl }\end{array}$ & $\begin{array}{l}\text { of } \\
\text { mentation }\end{array}$ & $\begin{array}{l}\text { Net Annual } \\
\text { Reoccurring } \\
\text { Costs }\end{array}$ & $\begin{array}{l}\text { Ist Year } \\
\text { Savings }\end{array}$ & $\begin{array}{l}7 \text { Yr LifeCycte } \\
\text { Savings }\end{array}$ & $\begin{array}{l}\text { LCS/C } \\
\text { Ratio }\end{array}$ \\
\hline Prejob Qualification Verification & $\$ 115$ & & $\$ 2.5 \mathrm{k}$ & $\$ 1,146 \mathrm{~K}$ & $\$ 8,689 \mathrm{k}$ & 75 \\
\hline
\end{tabular}

All costs are based on a mean crew size of eight.

Calculated as: (\$cost/incident $\times 238$ incidents/wk $\times \$ 2$ wks/yr) $\times 40 \%$

Calculated as: (\$cost/incident $\times 16$ incidents/wk $\times 52$ wks/yr) $\times 40 \%$

Calculated as: (Scost/incident $\times 5$ incidents/wk $\times 52$ wks $/ y r)$ x $40 \%$

Net: Calculated as: 1 Year Cost Savings - Cost of Implementation

Net: Calculated As: Lifecycle Saving (7 Yr) - Implementation Costs - Lifecycle Reoceurring Costs

Ratio of Lifecycle Costs / Implementation Costs 


\section{c. Formal Training For ACES Users}

Develop and implement two short courses for the various user functions of ACES that are specialized to the type of user-- ACES station operator (HPTs) and planners/PICs/supervisors. The courses would be made available to new users and for current users that desire a refresher. A course design goal would be to limit the ACES station operator class length to 2 hours, and the planners/PICs/Supervisor course to 1 hour. Computer-based-training should be considered, depending on cost. ${ }^{69}$ Consideration should be given to outsourcing the development of the classes and the instruction. All estimates are based on out-source rates.

\section{Adyantages}

- Users will be more inclined to using the system.

- By using the system with all of its features, cost savings can be maximized.

\section{Implementation Considerations}

- Users must find the time to attend.

- If usage is infrequent, users will continue to have difficulty.

\section{Implementation Steps/Schedule}

Table 14 is a summarization of the tasks required to implement this alternative.

\begin{tabular}{|l|l|l|l|l|l|}
\hline \multicolumn{2}{|l}{ Formal Training For ACES Users } & \multicolumn{3}{c}{ Table 14 } \\
\hline Subtask Description & Duration & Effort & Rate & Labor Cost & Total Cost \\
\hline \hline Project Control & 4 months & $82 \mathrm{hrs}$ & $\$ 65.49$ & $\$ 5.4 \mathrm{k}$ & $\$ 5.4 \mathrm{k}$ \\
\hline $\begin{array}{l}\text { Develop Training Package-- ACES } \\
\text { Station Operators }\end{array}$ & $\begin{array}{l}1.5 \\
\text { months }\end{array}$ & $225 \mathrm{hrs}$ & $\$ 69.00^{70}$ & $\$ 15.5 \mathrm{k}$ & $\$ 15.5 \mathrm{k}$ \\
\hline $\begin{array}{l}\text { Develop Training Package--Planners, } \\
\text { PICs, Supervisors }\end{array}$ & 1 month & $150 \mathrm{hrs}$ & $\$ 69.00$ & $\$ 10.4 \mathrm{k}$ & $\$ 10.4 \mathrm{k}$ \\
\hline $\begin{array}{l}\text { Perform Training At Site-ACES Station } \\
\text { Operators }\end{array}$ & 1 month & $150 \mathrm{hrs}$ & $\$ 69.00$ & $\$ 10.4 \mathrm{k}$ & $\$ 10.4 \mathrm{k}$ \\
\hline $\begin{array}{l}\text { Perform Training At Site-Planners, PICs, } \\
\text { Supervisors }\end{array}$ & 2 months & $300 \mathrm{hrs}$ & $\$ 69.00$ & $\$ 20.7 \mathrm{k}$ & $\$ 20.7 \mathrm{k}$ \\
\hline \hline
\end{tabular}

An estimate for developing a computer-based-training was not available for this study. Bids could be solicited once a decision to pursue the alternative is made, and a comparison made to traditional class-type estimate provided herein. Computer-based-training has the advantage of lower reoccurring costs (lower instnuctor costs.) 


\section{Reoccurring Costs}

Sub alternative 1.c would require provision of the training class for new or reassigned personnel, and those desiring a refresher for each year of the life cycle. This is estimated at 24 classes per year, 3 hours per class (including instructor preparation and travel.) Cost per year would be \$5k. Seven year LifeCycle cost would be $\$ 30 \mathbf{k}^{72}$.

\section{Cost Savings}

Cost savings for this alternative could not be quantified. However, interviews, reports, and observations indicate that there would be a cost savings in improved throughput and fewer declinations that would equal, and likely exceed, the cost of implementation and continued servicing (reoccurring costs of providing the training throughout the life cycle.)

Table 15 Summarizes the cost of implementation and net annual reoccurring costs.

\begin{tabular}{|l|l|l|l|l|l|}
\hline $\begin{array}{l}\text { Table 15 } \\
\text { Altemative Description }\end{array}$ & $\begin{array}{l}\text { Cost of } \\
\text { Implementation }\end{array}$ & $\begin{array}{l}\text { Net Annual } \\
\text { Recocurring } \\
\text { Costs }\end{array}$ & $\begin{array}{l}\text { 1st Year } \\
\text { Savings }\end{array}$ & $\begin{array}{l}7 \text { Yr LifeCycle } \\
\text { Savings }\end{array}$ & LCS/IC Ratio \\
\hline \hline Formal Training For ACES Users & $\$ 62 k$ & $\$ 5 k$ & Unknown & Unknown & Unknown \\
\hline & & & & & \\
\hline
\end{tabular}




\section{Redesign Current Process/ACES}

Table 16 is a summary of the subalternatives for Alternative 2. Details of each subalternative follow.

\begin{tabular}{|c|c|c|c|c|c|}
\hline $\begin{array}{l}\text { Table } 16 \\
\text { Alternative Description }\end{array}$ & $\begin{array}{l}\text { Cost of } \\
\text { Implementation }\end{array}$ & $\begin{array}{l}\text { Net Annual } \\
\text { Reoccurring } \\
\text { Costs }\end{array}$ & $\begin{array}{l}\text { 1st Year } \\
\text { Savings" }\end{array}$ & $\begin{array}{l}7 \text { Yr LifeCycle } \\
\text { Savings" }\end{array}$ & $\begin{array}{l}\text { LCS/IC } \\
\text { Ratio"s }^{*}\end{array}$ \\
\hline 2.a Decentralize/simplify ACES & S400k & s229k & S 3,314k & $524,220 \mathrm{k}$ & 60 \\
\hline 2.b Decentralize Key Control & $56.8 \mathrm{k}$ & No Change & $\$ 607 k$ & $\$ 4,292 \mathrm{k}$ & 630 \\
\hline 2.c Redesign Training Records Information (TRI) System & $5459 \mathrm{k}$ & $\$ \$ 112 k$ & $(\$ 186 k)$ & \$780k & 1.7 \\
\hline 2.d Implement Electronic Dosimetry & \$530k & $\$ 31 k$ & $\$ 76 \mathrm{k}$ & $\$ 3,529 k$ & 6.6 \\
\hline Total of Redesign Current Process/ACES & $\$ 1,396 \mathrm{k}$ & $\$ 372 k$ & $\$ 3,811 \mathrm{k}$ & $\$ 32,821 \mathrm{k}$ & 24 \\
\hline
\end{tabular}

\section{a. Decentralize/simplify ACES}

Sub alternative 2.a consists of two significant interdependent activities.

- Redesign the ACES user interface to current graphical, client-server technology. Client user interfaces would be optimized to support the decentralization and self-serve usage by team leads, PICs, or supervisors. Interface through the client process would be further simplified and streamlined using bar code or other machine readable technologies.

- Decentralize the ACES stations at 272 WA (200-West area) and 272AW (200-East area.) Replace these stations with 16 stations placed with the reengineered work teams that are currently being implemented within TWRS. Change the ACES stations at 2704HV, AY change trailer, AZ change trailer, and BY-BX change trailer to self usage.

\section{Redesign the ACES User Interface to Current Graphical. Client-Server Technology}

The current implementation affectively handles caching of data and enforcing the "business" rules and process logic centrally inside the Oracle database. The existing user interface is complex and cumbersome, and its use is limited to a few individuals for whom operating the system becomes their primary job.

Redesign of the ACES would extend it into a client/server environment. This environment distributes the transaction processing onto the "client" computer (or user's computer) end. The "server" provides the longterm storage and rapid retrieval of information and enforcement of common business rules. The load on the server is reduced by decreasing unnecessary client-specific processing (e.g., computer screen display, report formatting, keystroke validation) making it faster at responding to information requests and rule check processing. An example of a client-server application is the new TIS (time information system) used by the majority of M\&O contractor employees on the Hanford Site. Thousands of employees, many with limited computer skills, successfully use the system each week. 
New client user interfaces would be designed and built for specific job functions with uncluttering of superfluous choices and functions not required for the task at hand. The different types of specialized screens could include a shift/manager client, HPT client, a planner/PIC client, pocket dosimetry return/log-in client, RWP entry/maintenance client, location maintenance client and system maintenance client. ${ }^{76}$

A shift/manager client interface would support the addition/authorization of personnel to access lists, override training dates, allow the manager to deny access regardless of training, and poll ACES to determine current occupancy of specific work locations. It would also view, query and print lists of access status and training date expirations for workers and teams of workers. The shift/manager client would work with individuals and/or work teams.

The HPT client interface would provide functions to grant authorization to allow modifications and updates to the exposure records. It would also interface to the RWP database for maintenance. It would provide the capability to view, query, and print lists of access status and training date expirations for employees and employee teams. It would also support the functions of pocket dosimetry issuance and return.

The planner/PIC client would support the prequalification screening and point-of-entry validation of worker qualifications. Teams could be prequalified at the work-package planning stage for a specific range of dates, location, RWP, and job role. Any qualification issues could be documented and resolved prior to the job work date. On the date work starts, the prequalification package would be fetched and displayed, any required adjustments made (e.g., crewmember substitution or deletion because of absence), pocket dosimetry ID's entered for each worker (using bar code scanner), and the package submitted for final validation and clearance. All cross-checks would be completed by the computer which would return a go/no-go response. If the validation is declined, a simplified paper report would be provided which explains the reason(s) for declination.

The pocket dosimetry return/log in client would support the rapid processing of returned pocket dosimeters. Equipped with a bar code scanner, the operator simply would scan the pocket dosimeter's bar code and key-in the radiation exposure. Key-in entries would be checked immediately for reasonableness (e.g., a shaky finger registering a $10,000 \mathrm{mr}$ entry would sound a recheck tone.) Pocket dosimeters would be collected enmass at the end of shift, and they would be bulk-entered during the following shifts. ${ }^{77}$

The RWP entry/maintenance client would support the activities necessary for entering in new RWPs, or maintaining/removing the existing ones. The location maintenance client would support the activities necessary for entering or editing location information stored in ACES. The system maintenance client would support ACES system and administrator activities such as backups, new user authorization and activity privileges.

\section{Advantages}

- Eliminates major delays and idle time in getting workers validated and into the work areas.

- Easy-to-use graphical user interfaces for different users will lessen user difficulties and reduce time spent operating the system.

The descriptions and delineations provide herein are provided as initial conceptfunction information and magnitude budget estimates. They do not replace a comprehensive requirements specification, analysis, and design process which may provide more effective delineations. 
WHC-SD-WM-ES-397, REV 0

Page 29 of 64

- Provides management and supervision usable tools to meet their responsibilities of maintaining worker qualification knowledge and cognizance.

- Provide easy access.

- Reduces requirement for and time spent on training.

\section{Implementation Considerations}

- Requires a major shift in the responsibilities of PICs, supervisors, and HPTs.

- Requires many more individuals to become proficient in computer usage.

- May involve labor jurisdiction issues. 


\section{Implementation Steps/Schedule}

Table 17 is a summarization of the tasks required to implement this alternative.

\begin{tabular}{|c|c|c|c|c|c|c|}
\hline \multicolumn{3}{|l|}{ Decentralize/simplify ACES } & \multicolumn{4}{|r|}{ Table 17} \\
\hline Subtask Description & Duration & Effort & Rate & Labor Cost & Mtl Cost & Total Cost \\
\hline Project Control & 12 months & $410 \mathrm{hrs}$ & $\$ 65.49$ & $\$ 27 k$ & & $\$ 27 \mathrm{k}$ \\
\hline Upgrade Oracle DBMS & 3 months & $120 \mathrm{hrs}$ & $\$ 81.86$ & $\$ 10 k$ & \$25k & $\$ 35 k$ \\
\hline $\begin{array}{l}\text { Upgrade Oracle Server Database } \\
\text { Structures, Remote Procedures, Triggers }\end{array}$ & 2 months & $240 \mathrm{hrs}$ & $\$ 81.86$ & $\$ 20 k$ & & $\$ 20 k$ \\
\hline $\begin{array}{l}\text { Engineer \& Construct Client User } \\
\text { Interfaces }{ }^{z *}\end{array}$ & 9 months & $2700 \mathrm{hrs}$ & $\$ 81.86$ & S221k & & \$221k \\
\hline $\begin{array}{l}\text { Obtain \& Install Equipment (additional } \\
\text { computers, bar codie equipment) }\end{array}$ & 6 months & $240 \mathrm{hrs}$ & $\$ 81.86$ & $\$ 20 \mathrm{k}$ & $\$ 15 k$ & $\$ 35 \mathrm{k}$ \\
\hline $\begin{array}{l}\text { Rewrite Procedures and Other } \\
\text { Documentation }\end{array}$ & 6 months & $320 \mathrm{hrs}$ & $\$ 69.00$ & $\$ 22 k$ & & $\$ 22 \mathrm{k}$ \\
\hline Train Users, Migrate to New System & 3 months & 480 hrs & $\$ 81.86$ & \$39k & & $\$ 39 k$ \\
\hline Total & 12 months & $4510 \mathrm{hrs}$ & & $\$ 360 k$ & $\$ 40 \mathrm{k}$ & $5400 \mathrm{k}$ \\
\hline
\end{tabular}

\section{Reoccurring Costs}

Sub alternative 2.a would require continuous operations management and support, including response to trouble calls (as does the current ACES.) This support is estimated at one full time equivalent (FTE) or 1,820 hours per year. Complex systems such as these experience substantial requests for upgrades to further improve productivity (continuous improvement) and to meet changing needs. This support is estimated at .5 FTE or 910 hours per year. Continued offering of training classes for advanced users for each year of the life cycle would be required to ensure continued acceptance and productivity of the users. This is estimated at 24 classes per year, 3 hours per class (including instructor preparation and travel.) Cost per year would be $\$ 229 \mathrm{k}^{99}$. A seven-year LifeCycle cost would be $\$ 1,371 \mathrm{k}^{80}$. It should be noted that the existing ACES has very equivalent maintenance/operations costs. 


\section{Cost Savings}

Table 18 summarizes the process steps that would be effected by the alternative and the cost impact anticipated. Table 19 reconciles the cost of implementation with the anticipated cost savings.

\begin{tabular}{|c|c|c|c|c|}
\hline \multirow{2}{*}{$\begin{array}{l}\text { Decentralize/simplify ACES } \\
\text { Process Step/Function To Modify/Eliminate }\end{array}$} & \multicolumn{4}{|r|}{ Table 18} \\
\hline & $\begin{array}{l}\text { Cost / } \\
\text { Incident }\end{array}$ & $\begin{array}{l}1 \text { Year Cost } \\
\text { Savings }\end{array}$ & $\begin{array}{l}\text { Life cycle } \\
\text { Cost } \\
\text { Savings }\end{array}$ & Comments \\
\hline $\begin{array}{l}\text { ACES Checkout: (see page 7) } \\
\text { Travel to ACES Station }\end{array}$ & $\$ 80.00$ & $\$ 990 \mathrm{k}$ & $\$ 6,931 k$ & Eliminated by decentralization \\
\hline Wait in Line For Other Crews & $\$ 61.50$ & $\$ 609 k^{n 1}$ & $\$ 4,262 k^{n x}$ & $\begin{array}{l}\text { By decentralizing ACES stations, } \\
\text { reduces by } 80 \%\end{array}$ \\
\hline ACES Checkout & $\$ 112.85^{\circ}$ & $\$ 1,397 \mathrm{k}$ & $\$ 9,776 \mathrm{k}$ & \\
\hline Checkourt Pocket Dosimetry & NA & NA & NA & $\begin{array}{l}\text { No change, still required. Reduced in } \\
\text { Alternative } 2 . d \text {. }\end{array}$ \\
\hline Resolve Major Deslination & $\$ 592.00$ & $\$ 241 k^{m}$ & $\$ 1,689 \mathrm{k}^{\mathrm{ws}}$ & $\begin{array}{l}\text { Providing prejob qualification and mgr. } \\
\text { change client, reduce by } 49 \% \text {. }\end{array}$ \\
\hline Resolve Minor Declination & $\$ 247.00$ & $\$ 32 k^{*}$ & $\$ 220 k^{\prime \prime}$ & $\begin{array}{l}\text { Providing prejob qualification and mer. } \\
\text { change client, reduce by } 49 \% \text {. }\end{array}$ \\
\hline Manning ACES Station & $\begin{array}{l}\$ 10.7 \mathrm{k} / \\
\text { wk }\end{array}$ & $\$ 445 k^{\prime \prime}$ & $\$ 3,116 k^{*}$ & $\begin{array}{l}\text { Reduced by } 80 \% \text {. HPT's still need to } \\
\text { check-in pocket dosimetry, maintain } \\
\text { info in ACES }\end{array}$ \\
\hline Total & & $\$ 3,714 \mathrm{k}$ & $\$ 25,994 \mathrm{k}$ & \\
\hline
\end{tabular}

Calculated by: Cost/ncident x 238 Incidents/wk x 52 wks/yr $\times 80 \%$

Calcuiated by: Cost/Incident x 238 Incidents/wk x 52 wks/yr x 7 yr Life cycle x 80\%

Reduces Ops. process by $50 \%$, idle time by $80 \%$. Cost per incident calculates as $(0.4 \mathrm{hrs} \times 50 \%+2.8 \times 80 \%) \times 46.25 / \mathrm{hr}$.

Calculated by: Cost/incidents $\times 16$ Incidents/wk $\times 52$ wks/yr $\times 49 \%$

Calculated by: Cost/Incident x 16 Incidents/wk x 52 wks/yr x 7 yrs Life cycle x $49 \%$

Calculated by: Cost/ncidents x $\$$ Incidents/wk x 52 wks/yr x $49 \%$

Calculated by: CostIncident $x \$$ Incidents/wk $x \$ 2$ wks/yr $\times 7$ yrs LifeCycle $\times 49 \%$

Calculated by: $\operatorname{Cos} /$ wk to Man $\times 52$ wks/yr $\times 80 \%$

Calculated by: Cost/wk to Man x 52 wks/yr x 7 yrs x $80 \%$ 
WHC-SD-WM-ES-397, REV 0

Page 32 of 64

\begin{tabular}{|l|l|l|l|l|l|}
\hline $\begin{array}{l}\text { Table } 19 \\
\text { Atternative Description }\end{array}$ & $\begin{array}{l}\text { Cost of } \\
\text { Implementation }\end{array}$ & $\begin{array}{l}\text { Net Amual } \\
\text { Reoccurring } \\
\text { Costs }\end{array}$ & $\begin{array}{l}\text { 1st Year } \\
\text { Savings" }\end{array}$ & $\begin{array}{l}7 \text { Yr LifeCycle } \\
\text { Savings" }\end{array}$ & $\begin{array}{l}\text { LCS/IC } \\
\text { Ration }\end{array}$ \\
\hline \hline Decentralize/simplify ACES & $\$ 400 \mathrm{k}$ & $\$ 229 \mathrm{k}$ & $\$ 3,314 \mathrm{k}$ & $\$ 24,220 \mathrm{k}$ & 60 \\
\hline & & & & & \\
\hline
\end{tabular}

91 Net: Calculated as: Lifecycle Saving (7 Yr) - Implementation Costs - Lifecycle Reoccurring Costs 


\section{b. Decentralize Key Control}

Key control is centralized in the $200 \mathrm{E}$ and $200 \mathrm{~W}$ shift management offices, respectively. Sub alternative 2.b would distribute the majority of the keys to the 16 reengineered work groups, with backup keys available for checkout by shift management for seldom visited facilities, off-hour entry, or external work forces. This would eliminate much of the process and idle time discussed in section III.B.4. The work area supervisors or PIC would checkout keys to work crews on an as-needed basis as part of the prejob briefing. Personnel used primarily for checking out keys (key control clerk), although not totally eliminated, would be more available for altemative tasks.

\section{Advantages}

- Eliminates waiting in line/idle time of both the person obtaining a key and the remainder of the crew waiting to get to work.

- Delegates cognizant responsibility and control for knowledge of whom-is-doing-what to the reengineered teams that have been given that responsibility.

\section{Implementation Considerations}

- Loss of centralized control by the shift management.

- Additional and distributed responsibility for key control.

\section{Implementation Steps/Schedule}

Table 20 is a summarization of the tasks required to implement this alternative.

\begin{tabular}{|c|c|c|c|c|c|c|}
\hline \multicolumn{3}{|l|}{ Decentralize Key Control } & \multicolumn{4}{|r|}{ Table 20} \\
\hline Subtask Description & Duration & Effort & Rate & Labor Cost & Mt Cost & Total Cost \\
\hline Move/Procure Equipment ${ }^{33}$ & 3 days & $8 \mathrm{hrs}$ & $\$ 44.56$ & $\$ 0.4 \mathrm{k}$ & $\$ 1.0 \mathrm{k}$ & $\$ 1.4 \mathrm{k}$ \\
\hline Modify Procedures \& Documents & 36 days & $40 \mathrm{hrs}$ & $\$ 69.00$ & $\$ 2.8 \mathrm{k}$ & & $\$ 2.8 \mathrm{k}$ \\
\hline Training/ Turnover & 10 days & $32 \mathrm{hrs}$ & $\$ 81.84$ & $\$ 2.6 \mathrm{k}$ & & $\$ 2.6 \mathrm{k}$ \\
\hline Total & 36 days & $80 \mathrm{hrs}$ & & $\$ 5.8 \mathrm{k}$ & $\$ 1.0 \mathrm{k}$ & $\$ 6.8 \mathrm{k}$ \\
\hline
\end{tabular}

\section{Reoccurring Costs}

No reoccurring costs are expected. 


\section{Cost Sayings}

Table 21 summarizes the process steps that would be effected by the alternative and the cost impact anticipated. Table 22 reconciles the cost of implementation with the anticipated cost savings.

\begin{tabular}{|c|c|c|c|c|}
\hline Decentralize Key Control & & & & Table 21 \\
\hline Process Step/Function To Modify/Eliminate & $\begin{array}{l}\text { Cost } / \\
\text { Incident }\end{array}$ & $\begin{array}{l}1 \text { Year Cost } \\
\text { Savings }\end{array}$ & $\begin{array}{l}\text { LifeCycle } \\
\text { Svgs }(7 \mathrm{yr})\end{array}$ & Comments \\
\hline $\begin{array}{l}\text { Key Control Assignment: (see page 11) } \\
\text { Travel To \& From Key Control Station }\end{array}$ & $\$ 11.68$ & $\$ 115 k$ & S804k & Eliminated. \\
\hline Wait In Line & $\$ 5.84$ & $\$ \$ 7 k$ & $\$ 402 k$ & Eliminated. \\
\hline Key Checkout & $\$ 2.92$ & NA & NA & $\begin{array}{l}\text { No savings, it will still take time to } \\
\text { hand out/administer keys. }\end{array}$ \\
\hline Crew Waits & $\$ 133.31$ & $\$ 442 k$ & $\$ 3,093 \mathrm{k}$ & Eliminated. \\
\hline Resolve Declination & $? ?$ & NA & NA & Eliminated \\
\hline Total & & $\$ 614 k$ & $\$ 4,299 \mathrm{k}$ & \\
\hline
\end{tabular}

\begin{tabular}{|l|l|l|l|l|l|}
\hline $\begin{array}{l}\text { Table 22 } \\
\text { Altemative Description }\end{array}$ & $\begin{array}{l}\text { Cost of } \\
\text { Implementation }\end{array}$ & $\begin{array}{l}\text { Annual } \\
\text { Reoccuming } \\
\text { Costs }\end{array}$ & $\begin{array}{l}\text { 1st Year } \\
\text { Savings" }\end{array}$ & $\begin{array}{l}7 \text { Yr LifeCycle } \\
\text { Savings" }\end{array}$ & $\begin{array}{l}\text { LCS/C } \\
\text { Ratio* }\end{array}$ \\
\hline \hline Decentralize Key Control & $\$ 6.8 \mathrm{k}$ & No Change & $\$ 607 \mathrm{k}$ & $\$ 4,292 \mathrm{k}$ & 630 \\
\hline & & & & & \\
\hline
\end{tabular}




\section{c. Redesign Training Records Information (TRI) System}

Sub alternative 2.c would upgrade the existing TRI system and modify the process of authenticating and recording training information. The TRI system would be upgraded to a client-server architecture, with separate client "views" created to interact with the information, depending on the role of the user. In the current process, a student takes a course, may pass an exam, and an instructor uses a paper form to record the success. The form is passed to an authenticator, who verifies the information on the form, verifies the currency of qualifications of the instructor and approves the addition of information into the TRI database. The information is then entered into the TRI.

In the upgraded process and system, the TRI system would assume the responsibility for authentication. At course initiation, the course, instructor, and students would be authenticated. Modern client-server systems have the ability to authenticate personnel more readily and accurately than signature-based paper systems. The process is accepted per current policies (see references, section V, item 1.) On completion of the course, the necessary information would again be checked and the information added to the upgraded TRI data set. Paper records would also be printed, and hand-written signatures applied as back up. The course processing and authentication client primarily would be a compact, stand-alone application that easily could be distributed to instructors, both on and off site, including subcontractors. This application would have the capability of communicating with the Hanford Site host server via HLAN, phone line modem, or Internet link The function of the client could be integrated easily into computer based training (CBT) as a linkable module and provided to the subcontractors who write the CBT. Additional clients would be written to support the class and instructor administration, auditing, and reporting functions of the existing TRI.

Although sub alternative 2.c would save the training support function substantially through reduced authentication and data entry/maintenance costs, the analysis of this report is limited to the savings provided to TWRS operations.

\section{Advantages}

- Greatly reduces resources expended and resultant worker idle time caused by lack of real-time data records in both the TRI and ACES database management systems.

- Improves and standardizes the instructor qualification process, and provides positive authentication of instructor's qualification status prior to initiation of the course.

- Provides course-instructor-student qualification record traceability.

\section{Implementation Considerations}

- Requires acceptance and cooperation of the Site training organization(s).

- Complications in funding issues. 


\section{Implementation Steps/Schedule}

Table 23 is a summarization of the tasks required to implement this alternative.

\begin{tabular}{|c|c|c|c|c|c|c|}
\hline \multicolumn{3}{|l|}{ Redesign TRI System } & \multicolumn{4}{|r|}{ Table 23} \\
\hline Subtask Description & Duration & Effort & Rate & Labor Cost & Mtl Cost & Total Cost \\
\hline Project control & 12 months & $410 \mathrm{hrs}$ & $\$ 65.49$ & $\$ 27 k$ & & $\$ 27 k$ \\
\hline Upgrade to SQL server" & 6 months & $120 \mathrm{hrs}$ & $\$ 81.86$ & Siok & $\$ 30 \mathbf{k}$ & $\$ 40 \mathrm{k}$ \\
\hline $\begin{array}{l}\text { Migrate existing TRI database structure } \\
\text { and information to SQL Server. Create } \\
\text { required business rules, procedures, } \\
\text { triggers, remote queries. }\end{array}$ & 6 months & $910 \mathrm{hrs}$ & $\$ 81.86$ & $\$ 75 k$ & & $\$ 75 \mathrm{k}$ \\
\hline $\begin{array}{l}\text { Engineer and construct client user } \\
\text { interfaces }{ }^{98}\end{array}$ & 9 months & $2700 \mathrm{hrs}$ & $\$ 81.86$ & S221k & & S221k \\
\hline $\begin{array}{l}\text { Obtain and install equipment (additional } \\
\text { computers, bar code equipment) }\end{array}$ & 6 months & $240 \mathrm{hrs}$ & $\$ 81.86$ & $\$ 20 \mathrm{k}$ & $\$ 15 k$ & \$35k \\
\hline $\begin{array}{l}\text { Rewrite procedures and other } \\
\text { documentation }\end{array}$ & 6 months & 320 hrs & $\$ 69.00$ & $\$ 22 k$ & & $\$ 22 k$ \\
\hline $\begin{array}{l}\text { Train users, migrate to new' system, } \\
\text { operational tests }\end{array}$ & 3 months & 480 hrs & $\$ 81.86$ & $\$ 39 k$ & & $\$ 39 k$ \\
\hline Total & 12 months & $5180 \mathrm{hrs}$ & & $\$ 414 k$ & $\$ 45 k$ & $\$ 459 k$ \\
\hline
\end{tabular}

\section{Reoccurring Costs}

Sub alternative 2.c would require continuous operations management and support, including response to trouble calls (as does the current TRI system.) This support is estimated at 0.5 full time equivalent (FTE) or 910 hours per year. Complex systems such as these experience substantial requests for upgrades to further improve productivity (continuous improvement) and to meet changing needs. This support is estimated at 0.25 FTE or 450 hours per year. Although instructors would need very basic training to operate the system, they already require substantial briefing, and operational information could be added at negligible cost. Yearly cost is estimated at $\$ 112 \mathrm{k}$ per year. A 7 -year LifeCycle cost would be $\$ 670 \mathrm{k}^{\$ 9}$.

For 2 ea 200 MHZ Pentium-Pro Servers, 128 Mbyte RAM, MS-NT w/SQL-Server, 14 Gbyte RAID with online Optical Storage Archive. Also to be considered is using available space and resource on existing server (e.g. ACES server.) 


\section{Cost Savings}

Table 24 summarizes the process steps that would be effected by the alternative and the cost impact anticipated. Table 25 reconciles the cost of implementation with the anticipated cost savings.

\begin{tabular}{|c|c|c|c|c|c|c|}
\hline \multicolumn{2}{|l|}{ Redesign TRI System } & \multicolumn{5}{|c|}{ Table 24} \\
\hline \multicolumn{2}{|l|}{ Process Step/Function To Modify/Eliminate } & $\begin{array}{l}\text { Cost / } \\
\text { Incident }\end{array}$ & $\begin{array}{l}1 \text { Year Cost } \\
\text { Savings }\end{array}$ & $\begin{array}{l}\text { LifeCycle } \\
\text { Svgs (7y })\end{array}$ & \multicolumn{2}{|l|}{ Comments } \\
\hline \multicolumn{2}{|l|}{$\begin{array}{l}\text { ACES Checkout: (see page 7) } \\
\text { Travel to ACES Station }\end{array}$} & NA & NA & NA & \multicolumn{2}{|c|}{ Considered in alternative 2.a. } \\
\hline \multicolumn{2}{|l|}{ Wait in Line For Other Crews } & $\mathbf{N A}$ & NA & NA & \multicolumn{2}{|c|}{ Considered in alternative $2 . a$. } \\
\hline \multicolumn{2}{|l|}{ ACES Checkout } & NA & NA & NA & \multicolumn{2}{|c|}{ Considered in alternative 2.2} \\
\hline \multicolumn{2}{|l|}{ Checkout Pocket Dosimetry } & NA & NA & NA & \multicolumn{2}{|c|}{ Considered in alternative 2.d. } \\
\hline \multicolumn{2}{|l|}{ Resolve Major Declination } & $\$ 592.00$ & $\$ 241 k^{100}$ & $\$ 1,689 k^{101}$ & \multicolumn{2}{|c|}{$\begin{array}{l}\text { Providing prejob qualification and mgr. } \\
\text { change client, reduce by } 49 \% \text {. }\end{array}$} \\
\hline \multicolumn{2}{|l|}{ Resolve Minor Declination } & $\$ 247.00$ & $\$ 32 k^{202}$ & $\$ 220 k^{100}$ & \multicolumn{2}{|c|}{$\begin{array}{l}\text { Providing prejob qualification and mgr. } \\
\text { change client, rectuce by } 49 \% \text {. }\end{array}$} \\
\hline \multicolumn{2}{|l|}{ Manning ACES Station } & NA & NA & NA & \multicolumn{2}{|c|}{ Considered in altemative $2 . \mathrm{a}$} \\
\hline \multicolumn{2}{|r|}{ Total } & & $\$ 273 k$ & $\$ 1,909 \mathrm{k}$ & & \\
\hline $\begin{array}{l}\text { Table } 25 \\
\text { Altemative Description }\end{array}$ & \multicolumn{2}{|c|}{$\begin{array}{l}\text { Cost of } \\
\text { Implementation }\end{array}$} & $\begin{array}{l}\text { Net Annual } \\
\text { Reoccurring } \\
\text { Costs }\end{array}$ & $\begin{array}{l}\text { 1st Year } \\
\text { Savings }{ }^{14}\end{array}$ & $\begin{array}{l}7 \text { Yr LifeCycle } \\
\text { Savings }{ }^{109}\end{array}$ & $\begin{array}{l}\text { LCS/IC } \\
\text { Ratio }\end{array}$ \\
\hline $\begin{array}{l}\text { Redesign Training Records Information (TR) } \\
\text { System }\end{array}$ & \multicolumn{2}{|c|}{$5459 \mathrm{k}$} & $\$ 112 k$ & \multicolumn{2}{|l|}{$(\$ 186 k)$} & 1.7 \\
\hline & & & & & & \\
\hline
\end{tabular}

The quantifiable cost savings of sub alternative 2.c are low, with a return on investment (LCS/IC ratio) of only 1.7. This is because of scope limits of the study in identifying quantifiable cost savings. Actual savings would be substantially higher. Not considered in the study was the cost and effort required of managers, supervisors, and/or PICs in researching a resolving training record discrepancies in the prejob planning and crew assignment process stages. Interviews with managers, supervisors, and PICs suggested this effort was substantial. Also not considered was the savings to the training organizations this alternative would provide,

Calculated by: Cost/Incidents x 16 Incidents/wk x 52 wks/yr x $49 \%$

Calculated by: Cost/Incident x 16 Incidents/wk x 52 wks/yr $\times 7$ yrs LifeCycle x $49 \%$

Calculated by: Cost/Incidents x 5 Incidents/wk x 52 wks/yr x $49 \%$

Calculated by: Cost/Incident $\times 5$ lncidents/wk $\times 52$ wks/yr $\times 7$ yrs LifeCycle $\times 49 \%$

Net: Calculated as: 1 yr Cast Savings - Cost of Implementation

Net: Calculated As: Lifecycle Saving (7 Yr) - Cost of Implementation - Lifecycle Reoccurring Costs

Ratio of LifeCycle Costs / Implementation Costs 
WHC-SD-WM-ES-397, REV 0

Page 38 of 64

plus streamlining of the process and reduced processing and idle time afforded the student/worker. The gains, although not quantified in this study, could easily improve the LCS/IC ratio to 10 or more. Also to be considered is a joint funding arrangement between TWRS and the training organization. 


\section{d. Implement Electronic Dosimetry}

Electronic dosimetry is being used at the majority of commercial nuclear sites to supplement standard thermal luminescent dosimeters (TLD's.) Electronic dosimetry replaces the pocket or "pencil" type of dosimeter used to collect interim information between monthly readings of the TLD. The units are programmed and read by an electronic reader which interfaces to a computer station. The electronic dosimeters may be read, reset, preset with rate and maximum limits for alarming. Each are uniquely identified with an internal serial number that also can be read. Thus the units can be associated to an individual during any period of assignment (1 shift to permanent assignment.) Manufacturers include Alnor, Dositec, Merlin Gerin, SAIC, and Siemens.

The units would be coupled with the decentralized and modernized ACES control stations (sub alternative 2.a) described in section IV.B.2.a. Sub alternative 2.d would not be viable without sub alternative 2.a.

\section{Advantages}

- Improved radiation safety due to reduced errors from manual reading and logging of exposure information.

- Reduced cost of processing pocket dosimetry.

\section{Implementation Considerations}

- There may be labor issues to contend with.

- Periodic calibration would be required of the electronic dosimeters (as does the current pocket dosimetry.) The current service provider may not be capable of providing this service. 


\section{Implementation Steps/Schedule}

Table 26 is a summarization of the tasks required to implement this alternative.

\begin{tabular}{|c|c|c|c|c|c|c|}
\hline \multicolumn{3}{|l|}{ Implement Electronic Dosimetry } & \multicolumn{4}{|r|}{ Table 26} \\
\hline Subtask Description & Duration & Effort & Rate & Labor Cost & Mtl Cost & Total Cost \\
\hline Project Control & 12 months & $410 \mathrm{hrs}$ & $\$ 65.49$ & $\$ 27 k$ & & $\$ 27 k$ \\
\hline $\begin{array}{l}\text { Specify \& Procure Electronic Dosimeters } \\
\text { \& Readers }{ }^{107}\end{array}$ & 6 months & $440 \mathrm{hrs}$ & $\$ 81.86$ & $\$ 36 k$ & $\$ 340 k$ & $\$ 376 k$ \\
\hline $\begin{array}{l}\text { Engineer \& Construct Client User } \\
\text { Interfaces }{ }^{108}\end{array}$ & 6 months & $910 \mathrm{hrs}$ & $\$ 81.86$ & $\$ 75 k$ & & $\$ 75 k$ \\
\hline $\begin{array}{l}\text { Rewrite Procedures and Other } \\
\text { Documentation }\end{array}$ & 6 months & $320 \mathrm{hrs}$ & $\$ 69.00$ & $\$ 22 k$ & & $\$ 22 k$ \\
\hline $\begin{array}{l}\text { Train Users, Migrate to New System, } \\
\text { Operational Tests }\end{array}$ & 3 months & $360 \mathrm{hrs}$ & $\$ 81.86$ & $\$ 30 \mathrm{k}$ & & $\$ 30 k$ \\
\hline Total & 12 months & 2,440 hrs & & \$ 190k & $\$ 340 k$ & $\$ 530 k$ \\
\hline
\end{tabular}

\section{Reoccurring Costs}

This alternative would require additional maintenance for the electronic dosimeter readers, and an expected continued replacement of the electronic dosimeters due to malfunction, damage or loss. Maintenance of the additional equipment is estimated at 0.25 FTE or 455 hours / year. Replacement dosimeters is based on 5\% annual replacement, or 50 units per year. Yearly cost is estimated at $\$ 31 \mathrm{k} / \mathrm{yr}$. Seven year LifeCycle cost would be $\$ 186 \mathrm{k}^{109}$. 


\section{Cost Savings}

Table 27 summarizes the process steps that would be effected by the alternative and the cost impact anticipated. Table 28 reconciles the cost of implementation with the anticipated cost savings.

\begin{tabular}{|c|c|c|c|c|c|c|}
\hline \multicolumn{2}{|l|}{ Implement Electronic Dosimetry } & \multicolumn{5}{|c|}{ Table 27} \\
\hline Process Step/Function To Modify/Eliminate & & $\begin{array}{l}\text { Cost } f \\
\text { Incident } \\
\end{array}$ & $\begin{array}{l}1 \text { Year Cost } \\
\text { Savings }\end{array}$ & $\begin{array}{l}\text { LifeCycle } \\
\text { Svgs ( } 7 \mathrm{yr}) \\
\end{array}$ & Comments & \\
\hline $\begin{array}{l}\text { ACES Checkout: (see page 7) } \\
\text { Travel to ACES Station }\end{array}$ & & NA & NA & NA & Considered in sub alte & native 2.a. \\
\hline Wait in Line For Other Crews & & NA & NA & NA & Considered in sub alte & native $2 . \mathrm{a}$ \\
\hline ACES Checkout & & NA & NA & NA & Considered in sub alte & native 2. a. \\
\hline Checkout Pocket Dosimetry & & $\$ 49.00$ & $\$ 606 \mathrm{k}$ & $\$ 4.245 \mathrm{k}$ & & \\
\hline Resolve Major Declination & & NA & NA & NA & Considered in sub atre & native $2 . c$. \\
\hline Resolve Minor Declination & & NA & NA & NA & Considered in sub alte & native $2 . c$. \\
\hline Manning ACES Station & & NA & NA & NA & Considered in subalter & native $2 . a$ \\
\hline & Total & & $\$ 606 k$ & $\$ 4,235 \mathrm{~K}$ & & \\
\hline $\begin{array}{l}\text { Table } 28 \\
\text { Alternative Description }\end{array}$ & $\begin{array}{l}\text { Cost } \\
\text { Impl }\end{array}$ & of & $\begin{array}{l}\text { Annual } \\
\text { Reoccurring } \\
\text { Costs }\end{array}$ & $\begin{array}{l}\text { 1st Year } \\
\text { Savings }^{110}\end{array}$ & $\begin{array}{l}7 \text { Yr LifeCycle } \\
\text { Savings"I }\end{array}$ & $\begin{array}{l}\text { LCS/IC } \\
\text { Ratio }^{112}\end{array}$ \\
\hline Implement Electronic Dosimetry & $\$ 530$ & & $\$ 3 \mathbf{l k}$ & $\$ 76 \mathrm{k}$ & $\$ 3,529 \mathrm{k}$ & 6.6 \\
\hline
\end{tabular}




\section{Phased Replacement with Automated Site Entry System}

This altemative provides a multi-year, phased approach that considers the need for immediate action, but is realistic to budget cycles and funding constraints. With the subaltematives taken in order, it reduces risks of overall project failure due to funding reductions or technology challenges. Should the project be canceled or curtailed after one or two of the alternatives are completed, the money spent on the completed alternatives would continue to provide substantial savings.

\begin{tabular}{|c|c|c|c|c|c|}
\hline Alternative Description & $\begin{array}{l}\text { Cost of } \\
\text { Implementstion }\end{array}$ & $\begin{array}{l}\text { Net Anmugl } \\
\text { Reoccurring } \\
\text { Costs }\end{array}$ & $\begin{array}{l}\text { lst Year } \\
\text { Savings }\end{array}$ & $\begin{array}{l}7 \text { Yr Lifecycle } \\
\text { Savings }^{14}\end{array}$ & $\begin{array}{l}\text { LCS/IC } \\
\text { Ratio' }\end{array}$ \\
\hline 3.a- Administrative Improvements to Current Process & $\$ 196 k$ & \$7.5k & $\$ 1,742 \mathrm{k}$ & $\$ 1,742 k^{116}$ & 8 \\
\hline 3.b-Total of Redesign Current Process/ACES & $\$ 1,396 \mathrm{k}$ & $\$ 372 \mathrm{k}$ & $\$ 3,811 \mathrm{k}$ & $\$ 32,821 \mathrm{k}$ & 24 \\
\hline 3.c-Aurtomated Site Entry-Prototype/Pilot-Singie Farm & \$233k & None & NA & NA & NA \\
\hline 3.d-Implement Automated Site Entry- All Locations & S327k & $\$ 58 \mathrm{k}$ & $\$ 1,690$ & $\$ 13,444 \mathrm{k}$ & 41 \\
\hline $\begin{array}{l}\text { Total of Phased Replacement with Automated Site Entry } \\
\text { System }\end{array}$ & $\$ 2,154 k$ & $\$ 438 k$ & $\$ 7,243 k$ & S $48,007 \mathrm{k}$ & 22 \\
\hline
\end{tabular}

\section{a. Implement Alternative 1}

Implement the components of alternative 1 discussed in section IV.B.1, page 19. Implement with existing expense funding as soon as it can be made available (preferably in fiscal year 1997.)

\section{b. Implement Alternative 2}

Implement the components of alternative 2 discussed in section IV.B.2, page 27. Prioritize into the existing expense and CENRTC funding profiles as soon as possible (preferably in fiscal year 1997.)

\section{c. Implement Automated Site Entry Pilot/Prototype--Single Farm}

Sub alternative 3.c creates a further simplified qualification validation user interface for individual worker use. The system would be modeled after similar interfaces used in the commercial nuclear industry. It would lead to sub alternative 3.d, which places access control units at the entrance of all frequently used tank farms. The purpose of the sub alternative 3.c is not to achieve cost savings independent of other alternatives, but to develop and test the process and technology for further implementation in sub alternative $3 . \mathrm{d}$. This alternative requires the completion or simultaneous engineering and construction of alternative $3 . \mathrm{b}$, as it makes use of much the hardware and computer software being developed.

116 With altemative 3, altemative 3.1 is an interim cost saving measure to be in effect during the engineering and construction of alternative 3.2. It is replaced by alternative 3.2, and has no savings value beyond the implementation schedule of altemative 3.2 (approx 1 year.) The annual savings (net) in this case is the first year and life cycle savings, and is calculated as: Annual Savings (gross) - Implementation Costs- 1 Year Reoccurring Costs. 
If sub alternative 3.d is implemented directly without a pilot/prototype development, there would be a substantial risk of purchasing substantial hardware and software that would not function satisfactorily, resulting in disuse or replacement. Both the process and technology require one or more prototype-test-adjust design-retest cycles to ensure useability and acceptance of the process and validation of the technology. There are commercial implementations (see section IV.B.5, page 55) that generally have limitations that are difficult to overcome.

\section{Adyantages}

- Provides qualification validation and physical access control at the point of entry. No preliminary efforts are required.

- The total processing time for each individual is reduced to 20 to 30 seconds. No attendant or operator is needed.

- Workers could go from one job task to another in different areas, without having to return to supervision, ACES, and key control. Assignments/ assignment changes could be made over plant radio, while maintaining positive, real-time qualification validation and control. This would be particularly effective for maintenance, operations, and HPT personnel.

- Radiation dosage for each worker could be tracked to the location where received. This could help health-physics organization in determining expected area rates, and flag unusual situations that may need further attention.

- Reduces overall training costs

\section{Implementation Considerations}

- Requires each worker to become skilled in operating the system. However, system would not be any more complicated to operate than an automatic teller machine (ATM.)

- Requires remote equipment at sites, which may require more specialized maintenance than current ACES workstations. 


\section{Implementation Steps/Schedule}

Table 29 is a summarization of the tasks required to implement this alternative.

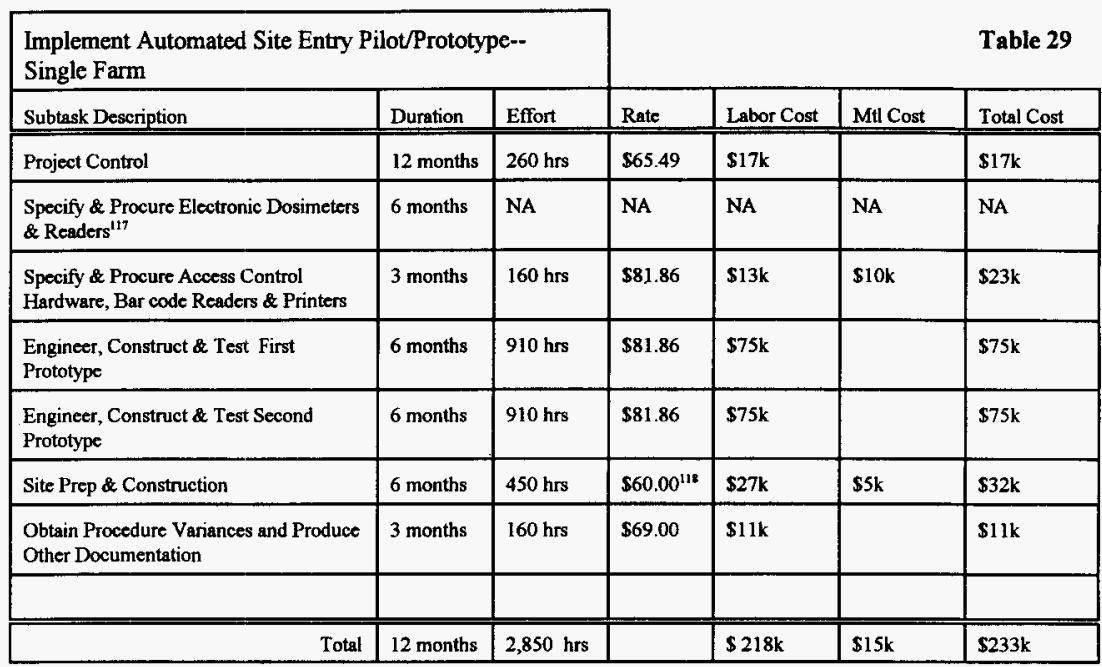

\section{Reoccurring Costs}

All costs for this alternative are contained in the initial implementation costs. This alternative does not extend beyond a pilot demonstration period, thus no reoccurring costs are anticipated.

\section{Cost Savings}

None anticipated for this prototype/pilot alternative. Need and cost savings for final implementation are outlined in alternative 3.d. 


\section{d. Implement Automated Site Entry- All Locations}

With sub alternative 3.d, the prototype/pilot automated site entry system of alternative 3.c is implemented in final configuration in the 13 most active locations, plus the shift offices for $200 \mathrm{~W}$ and $200 \mathrm{E}$ areas. ${ }^{119}$

\section{Advantages}

- Provides qualification validation and physical access control at the point of entry. No preliminary efforts are required.

- The total processing time for each individual is reduced to 20 to 30 seconds. No attendant or operator is needed.

- Workers could go from one job task to another in different areas, without having to return to supervision, ACES, and key control. Assignments/ assignment changes could be made over plant radio, while maintaining positive, real-time qualification validation and control. This would be particularly effective for maintenance, operations, and HPT personnel.

- Radiation dosage for each worker could be tracked to the location where received. This could help the health-physics organization in determining expected area rates and flag unusual situations that may need further attention.

- This alternative would provide substantial improvement in entry/exit and exposure records.

- With no additional cost, the alternative would provide personnel accountability for evacuation purposes.

- Training time and costs would be reduced.

\section{Implementation Considerations}

- Requires each worker to become skilled in operating the system. The system would not be any more complicated to operate than an automatic teller machine (ATM.)

- Requires remote equipment at sites, which may require more specialized maintenance than current ACES workstations. 


\section{Implementation Steps/Schedule}

Table 30 is a summarization of the tasks required to implement this alternative.

\begin{tabular}{|c|c|c|c|c|c|c|}
\hline \multicolumn{3}{|c|}{ Implement Automated Site Entry-- All Locations } & \multicolumn{4}{|r|}{ Table 30} \\
\hline Subtask Description & Duration & Effort & Rate & Labor Cost & Mtl Cost & Total Cost \\
\hline Projøct Control & 12 months & $410 \mathrm{hrs}$ & $\$ 65.49$ & S27k & & $\$ 27 \mathrm{k}$ \\
\hline $\begin{array}{l}\text { Engineer \& Construct Final Site Entry } \\
\text { User Interface System }{ }^{120}\end{array}$ & 6 months & $910 \mathrm{hrs}$ & $\$ 81.86$ & \$75k & & \$75k \\
\hline $\begin{array}{l}\text { Specify \& Procure Equipment (additional } \\
\text { computers, bar code equipment, } \\
\text { tumstiles, electronic locks) }\end{array}$ & 6 months & $240 \mathrm{hrs}$ & $\mathbf{\$ 8 1 . 8 6}$ & \$20k & \$50k & \$70k \\
\hline Site Prep \& Construction-15 Locations & 6 month & $1500 \mathrm{hrs}$ & $\$ 60.00^{121}$ & \$90k & $\$ 15 k$ & $\$ 105 k$ \\
\hline $\begin{array}{l}\text { Rewrite Procedures and Other } \\
\text { Documentation }\end{array}$ & 3 months & $160 \mathrm{hrs}$ & $\$ 69.00$ & $\$ 11 \mathrm{k}$ & & \$11k \\
\hline Train Users, Migrate to New System & 3 months & $480 \mathrm{hrs}$ & $\$ 81.86$ & $\$ 39 k$ & & $\$ 39 k$ \\
\hline Total & 12 months & $3700 \mathrm{hrs}$ & & $\$ 262 k$ & $\$ 65 k$ & $\$ 327 \mathrm{k}$ \\
\hline
\end{tabular}

\section{Reoccurring Costs}

Sub alternative 3.d would require continuous operations management and support, including response to trouble calls (as does the current ACES.) This support is estimated at 0.25 full time equivalent (FTE) or 455 hours per year (in addition to reoccurring costs for sub alternative 2.b.) Complex systems such as these experience substantial requests for upgrades to further improve productivity (continuous improvement) and to meet changing needs. This support is estimated at 0.25 FTE or 455 hours per year. Training for usage of the system can be incorporated into existing briefings, therefore, no additional reoccurring costs are anticipated. Reoccurring cost per year would be $\$ 58 \mathrm{k}^{\mathbf{1 2 2}}$. A 7-year LifeCycle cost would be \$345k. ${ }^{123}$ 


\section{Cost Savings}

Table 31 summarizes the process steps that would be effected by the alternative and the cost impact anticipated. Table 32 reconciles the cost of implementation with the anticipated cost savings.

\begin{tabular}{|c|c|c|c|c|}
\hline $\begin{array}{l}\text { Implement Automated Site Entry-- } \\
\text { All Locations }\end{array}$ & & & & Table 31 \\
\hline Process Step/Function To Modify/Eliminate & $\begin{array}{l}\text { Cost / } \\
\text { Incident }\end{array}$ & $\begin{array}{l}1 \text { Year Cost } \\
\text { Savings }\end{array}$ & $\begin{array}{l}\text { LifeCycle Cost } \\
\text { Savings }\end{array}$ & Comments \\
\hline $\begin{array}{l}\text { Key Control Awoignment: } \\
\text { Key Checkout (see page 11) }\end{array}$ & $\$ 2.92$ & $\$ 29 k$ & $\$ 201 k$ & $\begin{array}{l}\text { Savings of other key control activities } \\
\text { captured by other altematives. }\end{array}$ \\
\hline $\begin{array}{l}\text { Enter Controlled Work Area: } \\
\text { Log Entries (see page 13) }\end{array}$ & $\$ 24.82$ & $\$ 307 k$ & $\$ 2,150 \mathrm{k}$ & $\begin{array}{l}\text { No longer required. Maintained by } \\
\text { system. }\end{array}$ \\
\hline $\begin{array}{l}\text { Enit Controlled Work Area: } \\
\text { Log Entries (see page 14) }\end{array}$ & $\$ 24.82$ & $\$ 307 k$ & $\$ 2,150 \mathrm{k}$ & $\begin{array}{l}\text { No longer required. Maintained by } \\
\text { system. }\end{array}$ \\
\hline $\begin{array}{l}\text { Return Key \& Dosimetry (see page 14) } \\
\text { Travel to Aces \& Key Control Stations }\end{array}$ & $\$ 37.00$ & $\$ 458 \mathrm{k}$ & $\$ 3,205 k$ & \\
\hline Return Dosimeters & $\$ 37.00$ & $\$ 458 k$ & $\mathbf{S 3 , 2 0 5 k}$ & \\
\hline Retum Keys & $\$ 37.00$ & $5458 k$ & $\$ 3,205 \mathrm{k}$ & \\
\hline Return to Assigmment Area & NA & NA & NA & No savings, trip still required. \\
\hline Totals & & $\$ 2,017 \mathrm{k}$ & $\$ 14,116 k$ & \\
\hline
\end{tabular}

\begin{tabular}{|c|c|c|c|c|c|}
\hline $\begin{array}{l}\text { Table } 32 \\
\text { Alternstive Description }\end{array}$ & $\begin{array}{l}\text { Cost of } \\
\text { Implementation }\end{array}$ & $\begin{array}{l}\text { Net Annual } \\
\text { Reoccurring } \\
\text { Costs }\end{array}$ & $\begin{array}{l}\text { Ist Year } \\
\text { Savings }{ }^{124}\end{array}$ & $\begin{array}{l}7 \text { Yr LifeCycle } \\
\text { Savings }\end{array}$ & $\begin{array}{l}\text { LCS/IC } \\
\text { Ratio }^{134}\end{array}$ \\
\hline Implement Automated Site Entry- All Locations & $\$ 327 \mathrm{k}$ & $\$ 58 \mathrm{k}$ & $\$ 1,690 \mathrm{k}$ & $\$ 13,444 k$ & 41 \\
\hline
\end{tabular}




\section{Replace with Smart Card Site Entry System}

Smart Card technology allows individuals to carry with them the equivalent of four type-written pages of information. Applications of these credit card sized devices include automated point of entry, electronic signatures, and carrying of training, qualification and certification information.

A Smart Card is a computer (microprocessor, nonvolatile memory and foil contacts for external power and communication links) embedded in a credit card or security badge. Smart Card systems are cost effective alternatives to other storage devices like magnetic stripes, optical, bar code, proximity, and memory chip cards. Smart Cards have technologic advantages over the other alternatives including high degree of security, flexibility, positive user authentication and multifunction support.

Security advantages include storage of personal identification numbers, bio-identifiers (e.g., hand geometry, retinal scan) initial and continuous encrypted authentication challenges between the card and an interface terminal.

Flexibility of this technology includes storage of several distinct applications on a single card with safeguards against sharing of application data. User authentication capabilities provide positive identification electronic signatures which virtually prevent forgery. Multi-function features allow numerous applications and external computers the capability of intelligent responses to question-and-answer sessions.

Comparing training records, medical clearance qualifications and exposure information on an individual's Smart Card with access qualification criteria creates a very efficient automated point of entry The training records application of Smart Card technology incorporates various aspects of elements of the training process including verification/validation, updates, and automated conversion of offsite training to the central Hanford Site training database (TRI) ${ }^{127}$. Individuals completing any prerequisite medical clearance, badging, mask fit or training for tank farm entrance would leave with updated records on their Smart Card.

\section{The application of automated point of entry into the Tank Farm}

When an individual takes a class, goes for a mask fit, reads an RWP, or gets a physical, a Smart Card would be used to positively identify the individual, then record the results. A Smart Card interface terminal would be located where training is held, masks are fit, and physicals are performed to record the results. Additionally, each farm/zone entrance would require Smart Card interface terminal, with the entrance requirements (including radiation exposure expectations) for that area. Individual entering a controlled area inserts their assigned Smart Card, enters a personal identification number (PIN), and RWP working under (if required). The Smart Card interface compares the requirements for entry into the area it is guarding with the individual's qualifications. It looks checks the individual's current exposure record, adds the expected exposure for the area, and gives a go/no-go decision.

With a go decision, the user pulls an electronic dosimeter from a bin and slides it into an adjacent slot where it is zeroed and issued, the gate/turnstile unlocks, and the individual proceeds through. It takes from 20-30 seconds for the entire process. The person's presence is recorded in the interface station computer for evacuation accountability purposes. Upon exit, the Smart Card and electronic dosimeter are inserted, the exposure is read and transferred to the Smart Card. Exit information is recorded in the interface station, again for evacuation accountability.

On a no-go decision, a paper slip is provided with the reason for rejection so it can be corrected. There would be very few "false" rejections, since training records and other qualifications would be recorded immediately. 
Smart Card interface stations would still require communication with a central computer for the purposes of backup (e.g., card is lost or fails.) However, this interface would not have to be high throughput nor would the backup computer need to be large or complex. This computer would also provide "qualification expiring" messages (via cc:mail) to supervisors so they would be given ample time to correct.

\section{Advantages}

- Provides superior personnel identification capabilities, high resistance to tampering and unauthorized usage.

- Facilitates improved site security.

- Provides real-time information availability.

\section{Implementation Considerations}

- Cost and complexity in maintaining Smart Card security badges for all users.

\section{Implementation Steps/Schedule}

In this alternative, the primary data storage is contained in the individual Smart Cards. The ACES as it is currently constituted would be eliminated. The equipment would be reprogrammed to become an Archival Record and Personalization Server. This would provide the necessary backup and reporting functions. Although the implementation steps developed here continue and update the TRI system, if this alternative was to be explored further, consideration should be given to eliminating the separate TRI system and migrating the records and function to the Archival Record and Personalization Server as well. Additional savings may result. Table 33 is a summarization of the tasks required to implement this alternative. 


\begin{tabular}{|c|c|c|c|c|c|c|}
\hline \multicolumn{3}{|l|}{ Smart Card Point of Entry System } & \multicolumn{4}{|r|}{ Table 33} \\
\hline Subtask Description & Duration & Effort & Rate & Labor Cost & Mut Cost & Total Cost \\
\hline Project Control ${ }^{128}$ & 24 months & $2,400 \mathrm{hrs}$ & $\$ 65.49$ & $\$ 157 \mathrm{k}$ & & $\$ 157 k$ \\
\hline $\begin{array}{l}\text { Redesign Training Records Information } \\
\text { (TRI) System to support Smart Card }\end{array}$ & 12 months & $5180 \mathrm{hrs}$ & $\$ 79.92^{130}$ & $\$ 414 k$ & $\$ 45 \mathrm{k}$ & $\$ 459 \mathrm{k}$ \\
\hline $\begin{array}{l}\text { Redesign ACES to Become Archival } \\
\text { Record and Personalization Server }{ }^{128}\end{array}$ & 12 months & $4510 \mathrm{hrs}$ & $\$ 79.82$ & $\$ 360 \mathrm{k}$ & $\$ 40 k$ & $\$ 400 \mathrm{k}$ \\
\hline $\begin{array}{l}\text { Redesign HEHF Medical System to } \\
\text { Update Smart Cards }\end{array}$ & 3 months & $450 \mathrm{hrs}$ & $\$ 81.84$ & $\$ 37 k$ & & $\$ 37 \mathrm{k}$ \\
\hline $\begin{array}{l}\text { Engineer \& Construct Common Function } \\
\text { Software }^{131}\end{array}$ & 18 months & $2600 \mathrm{hrs}$ & $\$ 81.84$ & $\$ 213 k$ & & $\$ 213 k$ \\
\hline $\begin{array}{l}\text { Engineer \& Construct Personalization } \\
\text { Station Software }\end{array}$ & 12 months & $1900 \mathrm{hrs}$ & $\$ 81.84$ & $\$ 156 k$ & & $\$ 156 \mathrm{k}$ \\
\hline $\begin{array}{l}\text { Engineer \& Construct Update-Station } \\
\text { Software }^{131,156}\end{array}$ & 12 months & $1600 \mathrm{hrs}$ & $\$ 81.84$ & $\$ 131 \mathrm{k}$ & & $\$ 131 \mathrm{k}$ \\
\hline $\begin{array}{l}\text { Engineer \& Construct Verification } \\
\text { Station Software } e^{131,156}\end{array}$ & 14 months & $2100 \mathrm{hrs}$ & $\$ 81.84$ & $\$ 172 k$ & & $\$ 172 \mathrm{k}$ \\
\hline Design, Specify and Procure Hardware ${ }^{132}$ & 12 months & $1200 \mathrm{hrs}$ & $\$ 69.00$ & $\$ 83 k$ & $\$ 362 k$ & $\$ 445 k$ \\
\hline $\begin{array}{l}\text { Site Prep \& Construction- } 15 \\
\text { Locations }{ }^{123}\end{array}$ & 6 months & $1500 \mathrm{hrs}$ & $\$ 60.00^{133}$ & $\$ 90 k$ & $\$ 15 k$ & $\$ 105 k$ \\
\hline $\begin{array}{l}\text { Modify Infrastructure for System } \\
\text { Implementation } 31 \text {, 156 }\end{array}$ & 18 months & $\begin{array}{l}800 \mathrm{hrs} \\
2600 \mathrm{hrs} \\
\end{array}$ & $\begin{array}{l}\$ 81.86 \\
\$ 69.00 \\
\end{array}$ & $\begin{array}{l}\$ 65 k \\
\$ 179 k \\
\end{array}$ & & $\$ 244 k$ \\
\hline Total & 24 months & $\begin{array}{l}26,840 \\
\text { hrs }\end{array}$ & & $\$ 2,057 \mathrm{k}$ & S462k & $\$ 2,519 \mathrm{k}$ \\
\hline
\end{tabular}

\section{Reoccurring Costs}

The Smart Card altemative would require substantial maintenance and provision for updates to the system(s.) Table 34 Provides a summary of the costs.

The redeveloped Training Records Information system would require continuous operations management and support, including response to trouble calls (as does the current TRI system.) This support is estimated at 0.5 full time equivalent (FTE) or 910 hours per year. Complex systems such as these experience substantial requests for upgrades

Not considered in SAIC study (ref. 5)

The estimate for modifying Training Records System (TRI) for this atternative is the same as modifying TRI to better support ACES. For details, see section IV.B.2.c.

Composite rate of various resources. See section IV.B.2.c for detailed breakout.

Base estimate from SAIC study (ref. 5) with adjustments to current rates and conditions.

SAIC study estimated hardware costs only, additional cost (labor) for design, specification and procurement. SAIC study also underestimated number of units required substantially.

Composite rate of designer, engineer, PIC, and craft. 
to further improve productivity (continuous improvement) and to meet changing needs. This support is estimated at .25 FTE or 450 hours per year. Although instructors would need very basic training to operate the system, they already require substantial briefing and operational information could be added at negligible cost. Yearly cost is estimated at $\$ 112 \mathrm{k} / \mathrm{yr}$. Seven year LifeCycle cost would be $\$ 670 \mathrm{k}^{134}$.

The Archival Record and Personalization Server would require continuous operations management and support, including response to trouble calls (as does the current ACES.) This support is estimated at 1 full time equivalent (FTE) or 1820 hours per year. Complex systems such as these experience substantial requests for upgrades to further improve productivity (continuous improvement) and to meet changing needs. This support is estimated at . 5 FTE or 910 hours per year. Classes would be necessary for system users during the life cycle to ensure continued acceptance and productivity. This is estimated at 6 classes per year, 3 hours per class (including instructor preparation and travel.) Cost per year would be $\$ 224 k^{135}$. Seven year LifeCycle cost would be $\$ 1,341 \mathbf{k}^{136}$.

This alternative would require additional maintenance for the electronic dosimeter readers, and an expected continued replacement of the electronic dosimeters due to malfunction, damage or loss. Maintenance of the additional

equipment is estimated at 0.25 FTE or 455 hours / year. Replacement dosimeters is based on $5 \%$ annual replacement, or 50 units per year. Yearly cost is estimated at $\$ 31 \mathrm{k} / \mathrm{yr}$. Seven year LifeCycle cost would be $\$ 186 \mathrm{k}^{137}$.

The Personalization stations, Update Stations and Verification Stations (entrance gates) would require continuous maintenance. This is estimated at 1.5 FTE or 2730 hours per year (0.5 FTE maintenance craft, 1.0 FTE Engineering.) The Smart Cards would need periodic replacement due to malfunction, damage or loss. Replacements Smart Cards costs are estimated based on a $5 \%$ annual replacement. Note: Smart Cards can be reused. Yearly cost is estimated at $\$ 198 \mathrm{k}^{138}$. Seven year Life cycle cost would be $\$ 1,189 \mathrm{k}$.

Calculated as: Cost/yr $\times 6$ years. First year cost is included in the initial implementation costs. 
WHC-SD-WM-ES-397, REV 0

Page 52 of 64

\begin{tabular}{|c|c|c|c|c|c|c|}
\hline \multicolumn{3}{|c|}{ Reoccurring Cost: Smart Card Entry System } & \multicolumn{4}{|r|}{ Table 34} \\
\hline Reoccurring Cost Area & Hours/ Year & Rate & $\begin{array}{l}\text { Other } \\
\text { Costs } / \mathrm{yr}\end{array}$ & $\begin{array}{l}\text { Cost/ } \\
\text { Year }\end{array}$ & $\begin{array}{l}\text { Life cycle } \\
\text { Costs }(7 \mathrm{yr})\end{array}$ & Comments \\
\hline TRI System & 1,360 & $\$ 81.84$ & NA & $\$ 111 \mathrm{k}$ & $5668 \mathrm{k}$ & \\
\hline $\begin{array}{l}\text { Archival Record and Personalization } \\
\text { Server }\end{array}$ & 2,730 & $\$ 81.84$ & s1k & $\$ 225 \mathrm{k}$ & $\$ 1,348 \mathrm{k}$ & \\
\hline Electronic Dosimerry & 455 & $\$ 60.00$ & $\$ 15 k$ & $\$ 27 \mathbf{k}$ & \$164k & \\
\hline Smart Card & 2,730 & $\$ 69.98$ & $57 \mathrm{k}$ & $\$ 198 k$ & $\$ 1,189 \mathrm{k}$ & \\
\hline Totals & 7,275 & & $\$ 23 k$ & \$56Ik & $\$ 3,369 k$ & \\
\hline
\end{tabular}

\section{Cost Savings}

Table 35 summarizes the process steps that would be effected by the alternative and the cost impact anticipated. Table 36 reconciles the cost of implementation with the anticipated cost savings. 


\begin{tabular}{|c|c|c|c|c|}
\hline \multirow{2}{*}{$\begin{array}{l}\text { Smart Card Point of Entry System } \\
\text { Process Step/Function To Modify/Eliminate }\end{array}$} & \multicolumn{4}{|r|}{ Table 35} \\
\hline & $\begin{array}{l}\text { Cost / } \\
\text { Incident }\end{array}$ & $\begin{array}{l}1 \text { Year Cost } \\
\text { Savings }\end{array}$ & $\begin{array}{l}\text { Life cycle Cost } \\
\text { Sovings }\end{array}$ & Comments \\
\hline $\begin{array}{l}\text { ACES Checkout: (see page 7) } \\
\text { Travel to ACES Station }\end{array}$ & $\$ 80.00$ & $\$ 990 \mathrm{k}$ & $\$ 6,931 \mathbf{k}$ & Eliminated by decentralization \\
\hline Wait in Line For Other Crews & $\$ 61.50$ & $\$ 609 \mathrm{k}^{1200}$ & $S 4,262 k^{100}$ & By using point-of-entry, reduced $80 \%$. \\
\hline ACES Checkout & $\$ 112.85^{141}$ & $\$ 1,397 \mathbf{k}$ & $\$ 9,776 \mathbf{k}$ & \\
\hline Checkout Pocket Dosimetry & $\$ 49.00$ & $\$ 606 \mathrm{k}$ & $\$ 4,245 \mathrm{k}$ & \\
\hline Resolve Major Declination & $\$ 592.00$ & $\$ 483 k^{10}$ & $\$ 3,379 k^{10}$ & Reduced by $98 \%$. \\
\hline Resolve Minor Declination & $\$ 247.00$ & $\$ 63 k^{144}$ & $5440 k^{14 s}$ & Reduced by $98 \%$ \\
\hline Manning ACES Station & $\begin{array}{l}\$ 10.7 \mathbf{k} / \\
\mathbf{w k}\end{array}$ & $\$ 445 k^{140}$ & $\$ 3,116 \mathbf{k}^{10}$ & $\begin{array}{l}\text { Reduced by } 80 \% \text {. HPT's still need to } \\
\text { review dosimetry, maintain location \& } \\
\text { RWP info in Archive Server }\end{array}$ \\
\hline $\begin{array}{l}\text { Key Control Assignument: } \\
\text { Key Checkout (see page 11) }\end{array}$ & $\$ 2.92$ & $\$ 29 \mathbf{k}$ & $\$ 201 k$ & $\begin{array}{l}\text { Savings of other key control activities } \\
\text { captured by other alternatives. }\end{array}$ \\
\hline $\begin{array}{l}\text { Enter Controlled Work Area: } \\
\text { Log Entries (see page 13) }\end{array}$ & $\$ 24.82$ & $\$ 307 k$ & $\$ 2,150 \mathrm{k}$ & $\begin{array}{l}\text { No longer required. Maintained by } \\
\text { system. }\end{array}$ \\
\hline $\begin{array}{l}\text { Exit Controlled Work Area: } \\
\text { Log Entries (see page 14) }\end{array}$ & $\$ 24.82$ & $\$ 307 \mathbf{k}$ & $52,150 \mathrm{k}$ & $\begin{array}{l}\text { No longer required. Maintained by } \\
\text { system. }\end{array}$ \\
\hline $\begin{array}{l}\text { Return Key \& Dosimetry (see page 15) } \\
\text { Travel to Aces \& Key Control Stations }\end{array}$ & $\$ 37.00$ & $\$ 458 \mathrm{k}$ & $\$ 3,205 k$ & \\
\hline Retum Dosimeters & $\$ 37.00$ & $\$ 458 \mathrm{k}$ & $53,205 k$ & \\
\hline Return Keys & $\$ 37.00$ & $\$ 458 \mathrm{k}$ & $\$ 3,205 \mathrm{k}$ & \\
\hline Return to Assignment Area & NA & NA & NA & No auvings, trip still required. \\
\hline Total & & $\$ 6,610 \mathrm{k}$ & $\$ 46,265 k$ & \\
\hline
\end{tabular}

Calculated by: Cost/Incident x 238 Incidents/wk $\times 52$ wks/yr $\times 80 \%$

Calculated by: Costlancident x 238 Incidents/wk x 52 wks/yr x 7 yr Life cycle $\times 80 \%$

Reduces Ops, process by $50 \%$, idle time by $80 \%$. Cost per incident calculates as $(0.4 \mathrm{hrs} \times 50 \%+2.8 \times 80 \%) \times 46.25 / \mathrm{hr}$.

Calculated by: Cost/Incidents x 16 Incidents/wk x 52 wks/yr x $98 \%$

Calculated by: Cost/Incident $\times 16$ Incidents $/$ wk $\times 52$ wks $/ y$ r $\times 7$ yrs Life cycle $\times 98 \%$

Calculated by: Cost/Incidents x \$ Incidents/wk x $\$ 2$ wks/yr x $98 \%$

Calculated by: Cost/Incident $\times 5$ incidents/wk $\times 52$ wks/yr $\times 7$ yrs Life cycle $\times 98 \%$

Calculated by: Cost/wk to Man x 52 wks/yr x $80 \%$

Calculated by: Costwk to Man x: 52 wks/yr x 7 yrs x $80 \%$ 
WHC-SD-WM-ES-397, REV 0

Page 54 of 64

\begin{tabular}{|l|l|l|l|l|l|}
\hline $\begin{array}{l}\text { Table 36 } \\
\text { Altemative Description }\end{array}$ & $\begin{array}{l}\text { Cost of } \\
\text { Implementation }\end{array}$ & $\begin{array}{l}\text { Net Annual } \\
\text { Reoccuring } \\
\text { Costs }\end{array}$ & $\begin{array}{l}\text { 1st Year } \\
\text { Savings }\end{array}$ & $\begin{array}{l}\text { 7.Yr. Life } \\
\text { cycle } \\
\text { Savings }\end{array}$ & $\begin{array}{l}\text { LCS/10 } \\
\text { Ratio }\end{array}$ \\
\hline \hline Smart Card Point of Entry System & $\$ 2,519 \mathrm{k}$ & $\$ 561 \mathrm{k}$ & $\$ 4,091 \mathrm{k}$ & $\$ 40,377 \mathrm{k}$ & 16 \\
\hline & & & & & \\
\hline
\end{tabular}

In review of the Smart Card alternative, it appears the cost of implementation is higher than altemative 3 (also a worker operated entrance control system) with a lower life cycle savings (net.) Thus, quantitatively, the Smart Card alternative is not a good choice. However, other qualitative considerations should be factored into the final decision. The Smart Card provides a superior positive personnel identification and system security, although no quantitative cost advantage was found for improved security. It may be more useable and expandable for the entire site. These could not be addressed in the scope of the study. 


\section{Purchase and Implement Commercial System (Replace Existing)}

Alternative 5 considers the procurement and implementation of a commercial access/radiological control system. Vendor systems from Canberra Industries ${ }^{151}$ and Pro-Tem. ${ }^{152}$ An active system was viewed at the Washington Public Power Supply System (WPPSS) plant WNP-2 (a combination of multiple vendor systems.) Phone interviews were held with users at Rocky Flats, who use the Canberra system. Neither vendor provided cost estimates for an entire turn-key system, or included cost estimates for life cycle costs. The estimates provided within this report are based on a composite of vendor-provided costs plus onsite estimates.

Alternative 5 would result in a system that was functionally equivalent to the end-product of Alternative 3 . It would include the retirement and replacement of ACES and TRI with a commercially provided system. Alternative 5 provides electronic dosimetry and active site entrance control. It does not implement Smart Cards.

\section{Advantages}

- Reduced maintenance and operations cost (not supporting multiple systems, e.g., ACES and TRI)

\section{Implementation Steps/Schedule}

In this altemative, a specification would be written for the system components; vendor support for migration of existing data; training of both technical, maintenance and using personnel; and continued implementation/operation support. Neither of the vendors provided construction support required for entrance modifications or other facilities. Table 37 Provides a summary of the implementations steps, costs, and schedule. 


\begin{tabular}{|c|c|c|c|c|c|c|}
\hline \multicolumn{3}{|c|}{ Commercial Entrance/Radiological Control System } & \multicolumn{4}{|r|}{ Table 37} \\
\hline Subtask Description & Duration & Effort & Rate & Labor Cost & Mtt Cost & Total Cost \\
\hline Project Control & 24 months & $1690 \mathrm{hrs}$ & $\$ 65.49$ & $\$ 111 k$ & & $\$ 111 \mathrm{k}$ \\
\hline Prepare specifications/procurement ${ }^{133}$ & 12 months & 5,460 hrs & $\$ 69.00$ & $\$ 377 \mathbf{k}$ & $\$ 45 k$ & $\$ 422 k$ \\
\hline $\begin{array}{l}\text { Commercial System: }:^{134} \\
\text { Site License } \\
\text { Software Sourcecode } \\
\text { Dual IBM AS-400/w db2 } \\
40 \text { Entrance Stations }{ }^{15 s} \\
\text { Electronic Dosimeters }{ }^{156} \\
\text { Mods to interface HEHF/REX } \\
\text { On-sile implementation support } \\
\text { and training }\end{array}$ & 6 months & NA & NA & NA & $\begin{array}{ll}\$ \quad 800 k \\
\$ 1,000 k \\
\$ \quad 250 k \\
\$ 241 \mathrm{k} \\
\$ \quad 600 \mathrm{k} \\
\$ \quad 20 \mathrm{k} \\
\$ \quad 72 \mathrm{k}\end{array}$ & $\$ 2,983 \mathrm{k}$ \\
\hline Modify PNNL REX to interface & 3 months & $450 \mathrm{hrs}$ & $\$ 81.84$ & $\$ 37 \mathbf{k}$ & & $\$ 37 \mathrm{k}$ \\
\hline $\begin{array}{l}\text { Modify HEHF Medical system to } \\
\text { interface }\end{array}$ & 3 months & 450 hrs & $\$ 81.84$ & $\$ 37 \mathbf{k}$ & & $\$ 37 \mathrm{k}$ \\
\hline $\begin{array}{l}\text { Engineering, QA \& technical support } \\
\text { during procurement and implementation }\end{array}$ & 18 months & $2,600 \mathrm{hrs}$ & $\$ 81.84$ & $\$ 213 k$ & & $\$ 213 k$ \\
\hline Site Prep \& Construction-40 Locations & 12 months & $4,500 \mathrm{hrs}$ & $\$ 60.00^{157}$ & $\$ 270 \mathrm{k}$ & $\$ 50 \mathrm{k}$ & $\mathbf{5 3 2 0 \mathrm { K }}$ \\
\hline $\begin{array}{l}\text { Modify Infrastructure for System } \\
\text { Implementation }{ }^{18}\end{array}$ & 18 months & $\begin{array}{l}800 \mathrm{hrs} \\
2,600 \mathrm{hrs} \\
\end{array}$ & $\begin{array}{l}\$ 81.86 \\
\$ 69.00 \\
\end{array}$ & $\begin{array}{l}\$ 62 k \\
\$ 179 k \\
\end{array}$ & & $\$ 241 k$ \\
\hline Total & 24 months & $18,550 \mathrm{hrs}$ & & $\$ 1,286 \mathrm{k}$ & $\$ 3,078 \mathrm{k}$ & $\$ 4,364 \mathrm{k}$ \\
\hline
\end{tabular}

\section{Reoccurring Costs}

Altemative 5, would require substantial maintenance and provision for updates to the system(s.) Table 38 Provides a summary of the costs.

The commercial system for Alternative 5 would require continuous operations management and support, including response to trouble calls (as do the current systems and all alternatives.) This support is estimated at 1 full time equivalent (FTE) or 1820 hours per year. Complex systems such as these experience substantial requests for upgrades to further improve productivity (continuous improvement) and to meet changing needs. This support is estimated at .5 FTE or 910 hours per year. Classes would be necessary for system users during the life cycle to ensure

Includes QAQC (verification \& validation) efforts appropriate for procurement of ADPE which processes personnel radiological overexposure information that with undetected error could result in radiological dose overexposure of personnel. See reference 3.

Based on estimate provided by Pro-Tem, Inc.

Because ACES and TRI are replaced in Alternative S, all existing access sites (e.g. 222-S labs, K-Basins) would require replacement.

Based on an initial implementation of 2,000 dosimeters (required for all ACES using facilities, not just tank farms.)

Calculated as: $\$ 300 / \mathbf{e}$ dosimeter $\times \mathbf{2 , 0 0 0}$

Composite rate of designer, engineer, PIC, and craft.

Change procedures, negotiation cosis between site business units, resolve differences. 
continued acceptance and productivity. This is estimated at 6 classes per year, 3 hours per class (including instructor preparation and travel.) Cost per year would be $190 \mathbf{k}^{159}$. Seven year Life cycle cost would be $\$ 1,138 \mathbf{k}^{160}$. Estimate is based on this support being provided by the system vendor.

This alternative would require additional maintenance for the electronic dosimeter readers, and an expected continued replacement of the electronic dosimeters due to malfunction, damage or loss. Maintenance of the additional equipment is estimated at 0.5 FTE or 910 hours per year. Replacement dosimeters is based on $5 \%$ annual replacement, or 100 units per year. Yearly cost is estimated at $\$ 72 \mathrm{k}$ per year. ${ }^{161}$ Seven year Life cycle cost would be $\$ 433 \mathrm{k}$. Maintenance would be provided by site maintenance personnel.

The entrance stations would require continuous maintenance. This is estimated at 1.0 FTE maintenance craft or 1820 hours per year. Yearly cost is estimated at $\$ 84 \mathbf{k}^{\mathbf{1 6 2}}$. Seven year Life cycle cost would be $\$ 505 \mathrm{k}$. Maintenance would be provided by site maintenance personnel.

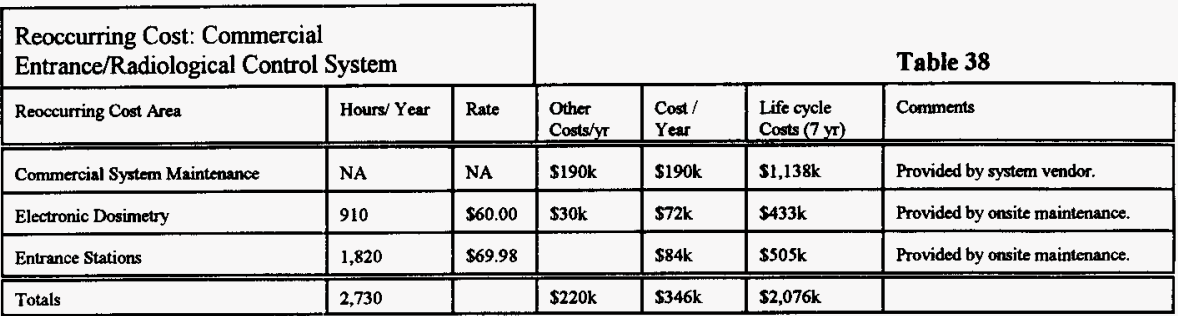

\section{Cost Savings}

Table 39 summarizes the process steps that would be effected by the alternative and the cost impact anticipated. Table $\mathbf{4 0}$ reconciles the cost of implementation with the anticipated cost savings. 


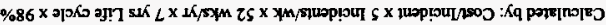

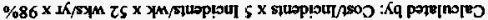

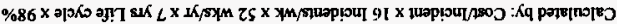

\begin{tabular}{|c|c|c|c|c|}
\hline & $x 5 \triangleright 0^{t} 9 \triangleright \$$ & $96 \angle 5^{4} 9 \$$ & & [E]०I \\
\hline \multirow[t]{4}{*}{ pannbas IIt?s dun sfunces oN } & $\mathrm{VN}$ & VN & VN & 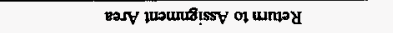 \\
\hline & Ysoz'cs & $185+5$ & 00:LEs & sরay umpy \\
\hline & Ysoz'cs & $185 \$ 5$ & $00 \angle E S$ & smpunsod umpy \\
\hline & শsoz'ES & 18sts & 00 LEs & 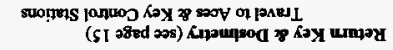 \\
\hline 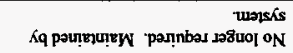 & Yosi'zs & YLOES & $28+2 \$$ & 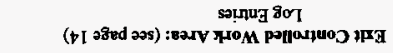 \\
\hline 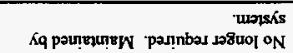 & YOSI'zs: & YLOES & $z 8 \div z s$ & 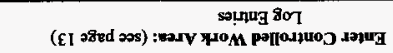 \\
\hline 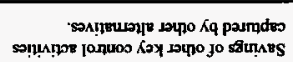 & Xiozs & Y625 & 2625 & 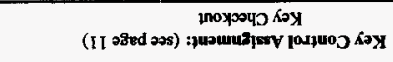 \\
\hline 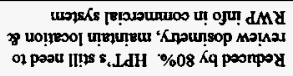 & tu1'9 I'ES & wilstts & IXLOOIS & 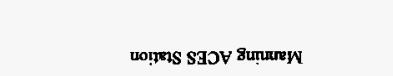 \\
\hline \%86 Кq posnpoy & «10zzs & myzes & $00 \angle t 2 S$ & 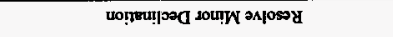 \\
\hline \multirow[t]{3}{*}{$\% 86$ Кq posnpoy } & $\triangle 1 \% \angle E t E S$ & mXests & $00^{\circ} 265 \$$ & นo!̣ะU! \\
\hline & XStZ゙'ヤS & $1909 \$$ & 0065 & Anaunsod loypod inospatio \\
\hline & Y9LL'6S & Y YL6E'IS & $\operatorname{son} 58 \mathrm{z} z \mathrm{ItS}$ & Inохрчบ SaวV \\
\hline 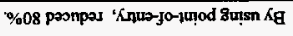 & mYZTZ"৮s & m609s & $0 S t 9 s$ & 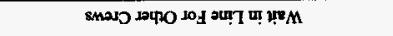 \\
\hline 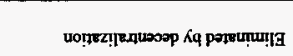 & પ્રાE6"9S & Y066S & 00085 & 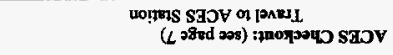 \\
\hline squatuluop & 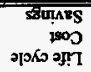 & $\begin{array}{l}\operatorname{sintants} \\
\operatorname{son} \sin \alpha I\end{array}$ & $\begin{array}{c}\text { Pu्plot? } \\
/ \text { / }\end{array}$ & 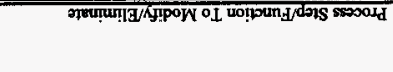 \\
\hline 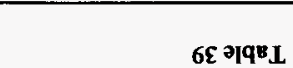 & & & & 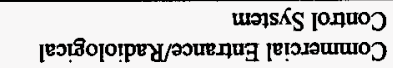 \\
\hline
\end{tabular}


WHC-SD-WM-ES-397, REV 0

Page 59 of 64

\begin{tabular}{|c|c|c|c|c|c|}
\hline $\begin{array}{l}\text { Table } 40 \\
\text { Alternative Description }\end{array}$ & $\begin{array}{l}\text { Cost of } \\
\text { Implementation }\end{array}$ & $\begin{array}{l}\text { Net Annual } \\
\text { Reoccurring } \\
\text { Costs }\end{array}$ & $\begin{array}{l}\text { 1st Year } \\
\text { Savings" }^{12}\end{array}$ & $\begin{array}{l}\text { 7-Yr. Life cycle } \\
\text { Savingss }\end{array}$ & $\begin{array}{l}\text { LCS/C } \\
\text { Ratio }^{174}\end{array}$ \\
\hline $\begin{array}{l}\text { Commercial Entrance/Radiological Control } \\
\text { System }\end{array}$ & $\$ 4,364 \mathrm{k}$ & \$346k & $\$ 2,215 \mathrm{k}$ & \$ $39,605 k$ & 9 \\
\hline & & & & & \\
\hline
\end{tabular}

Net: Calculated as: 1 Year Cost Savings - Cost of Implementation

173 Net: Calculated As: Life Cycle Saving (7 Yr) -Cost of Implementation - Life Cycle Reoceurring Costs

174 Ratio of Life cycle Costs / Implementation Costs 


\section{REFERENCES}

1. WHC-CM-3-1, "Management Requirements and Procedures"

MRP 2.1 "Signature Authority"

3. WHC-CM-4-2, "Quality Assurance Manual"

QR 19 "Software Quality Assurance Requirements"

4. WHC-SD-WM-HSP-002, “Tank Farm Health and Safety Plan (HASP)”, Revision 2F, Dated 7/3 1/96

5. Study, "SMART CARD OPPORTUNITY ASSESSMENT for the Hanford Site", Science Applications International Corporation, February 18, 1994.

6. Electronic Mail Message, William A. Decker, Subject: ACES Observations, Dated April 2, 1996 


\section{APPENDIX A-EXHIBITS}

\section{EXHIBIT I - SERVICE LINE PROCESSING}

The following table illustrates the lost time incurred by processing a crew of eight people one by one through the ACES station. It assumes that there are no declinations or other personnel ahead in the queue and that an ACES operator is available immediately. When arriving, the first crew member begins ACES processing, taking 3 minutes. Remaining members 2-8 each are idle 3 minutes, for a total idle time of 21 minutes. Then, the second member begins processing, members 1 and 3-8 are idle, again for a collective idle time of 21 minutes. The process continues through all crew members. For this example of eight crew members, collective processing time is 24 minutes, with collective idle time of 168 minutes for all crew members. Processing time is linear with increasing number of crew members, and idle time is exponential.

Example of Collective Process and Idle Time, ACES Service Line Processing

\begin{tabular}{|c|c|c|c|c|c|c|c|c|}
\hline Crew Member & 1 & 2 & 3 & 4 & 5 & 6 & 7 & 8 \\
\hline \hline I & S & W & W & W & W & W & W & W \\
\hline 2 & W & & W & W & W & W & W & W \\
\hline 3 & W & W & & W & W & W & W & W \\
\hline 4 & W & W & W & & W & W & W & W \\
\hline 5 & W & W & W & W & & W & W & W \\
\hline 6 & W & W & W & W & W & & W & W \\
\hline 7 & W & W & W & W & W & W & & W \\
\hline 8 & W & W & W & W & W & W & W & \\
\hline & 21 & 21 & 21 & 21 & 21 & 21 & 21 & 21 \\
\hline $\begin{array}{l}\text { Total Idle Time } \\
\text { 168 Minutes }\end{array}$ & & & & & & & & \\
\hline
\end{tabular}

where

$$
\begin{aligned}
& W=\text { waiting time (idle) } \\
& P=\text { process time ( } 3 \text { minutes) }
\end{aligned}
$$

Formulas:

$$
\begin{aligned}
& \mathrm{Tp}=\text { Total Crew Processing Time } \\
& \mathrm{Pt}=\text { Mean Processing Time } \\
& \mathrm{Nc}=\text { Number in Crew } \\
& \mathrm{Ti}=\text { Total Crew Idle Time } \\
& \mathrm{Tp}=\text { Nc } \times \text { Pt } \\
& \mathrm{Ti}=\mathrm{Pt} \times \mathrm{Nc}(\mathrm{Nc}-1)
\end{aligned}
$$




\section{EXHIBIT II-- ACES PROCESS SEQUENCE}

This exhibit illustrates the access requirement procedure.

The process requirements shown here consists of:

19 data entries

6 menu selections

This process is neither user friendly nor efficient.

\section{ACES CLEARANCE PROCEDURE}

1. DESCRIPTION: Bring up client name

BEGIN: Main Menu on screen
a. Bring up Master Date Menu
b. Request client employee or I.D. number
c. Enter identification number
d. Read client name
e. Verify client name
f. Return to Master Data menu

2. DESCRIPTION: View and verify Work Location (ACE611)

BEGIN: Main Menu on screen
a. Select Enter/Update Location file
b. Bring up Enter/Location file
c. Establish a file query
d. Move to Parent Complex field
c. Complete a Parent Complex query
f. Select appropriate work location item(s)
g. Move to Enter/Update Work Location block
h. View work location
I. Return to Master Data Menu

3. DESCRIPTION: View and verify Permit Requirements (ACE314) BEGIN: Main Menu on screen
a. Call up Access Requirements Menu
b. Call up Enter/Update file
c. Initiate permit and requirements query
d. Enter permit number
e. Retrieve the file records 
f. Verify 8 permit status parameters

$\begin{array}{ll}\text { - } & \text { Permit No } \\ & \text { Type } \\ & \text { Status } \\ \text { - } & \text { (S)start (D)date } \\ & \text { End Date } \\ & \text { Pencil/Brick } \\ & \text { Description } \\ \text { View permit requirements } \\ \text { Exit to Access Requirements Menu }\end{array}$

4. DESCRIPTION: View and verify Location Requirements (ACE316)

BEGIN: Main Menu on screen
a. Call up Enter/Update Locations and Requirements file
b. Initiate a location requirements inquiry
c. Enter Complex in complex field
d. Move to Work Location field
e. Enter work location
f. Complete the work location query
g. Move to Location requirements block
h. View Work location requirements
I. Exit to Access Requirements Menu

5. DESCRIPTION: View and verify Role Requirements (ACE322)

\section{BEGIN: Main Menu on screen}
a. Call up Enter/Update Roles and Requirements
b. Initiate role inquiry
c. Enter role identifier
d. Complete inquiry
e. Move to Enter/Update Role Requirements block
f. View role requirements
g. Return to Access Requirement
h. Return to Main Menu 


\section{EXHIBIT III-- ACES OVERVIEW}

\section{ACES Overview:}

ACES is a multi-function application that was developed to replace the Westinghouse radiation monitoring system (WRAM) Near the end of its software life cycle, the WRAM database experienced many technical problems typical of obsolete legacy file-based databases (Paradox files on OS/2 fileservers). Problems included scaling the number of concurrent users working on WRAM, loss of data integrity during network failures, and reliable data replication for backup purposes.

ACES was conceived to handle the underlying problems of WRAM with the key concepts of scalability, extendibility and server side transaction processing. ACES was developed with strict design practices, verification, validation, and quality assurance overview (see reference 3) appropriate to its major and significant role in protecting workers from radiological overexposure and ensuring that worker qualifications are met for the hazard exposures and type of work performed. Activities included preliminary system requirements gathering, semantic data modeling, software coding, verification/validation, development of acceptance test criteria, and users/training manuals. These set of practices helped encapsulate into a database the "business" rules and process logic of person performing work in a radiological or hazardous material control area. ACES was brought into production in May 1995.

The current implementation of the ACES is a high end SUN'Microsystems SPARC Server 1000 with two microprocessors, 512 megabytes of RAM and 6 gigabytes of physical disk space. The software consists of SUN Solaris 2.3 operating system and an Oracle ${ }^{2} V$. XX relational database. The high end SPARCServer with Solaris 2.3 provides a highly available and reliable hardware platform to scale (both data and concurrent users) well beyond the old $386 / 486 \mathrm{OS} / 2$ fileservers.

The Oracle database acts as a multipurpose central repository of data. Some of the functions include collecting and integrating data from various onsite record databases including REX, HEHF, TRI and PeopleCore. The purpose of this database is to cache all the required data in order to determine whether a worker is qualified perform the work in a particular hazardous location. This caching feature allows faster querying of the data over performing real time queries into the various record databases. Another function of the Oracle database is to store the "business" rules and process logic that is required to determine worker access from the cached data. This multi-tier database architecture alleviates the majority of the problems that WRAM faced.

The largest drawback with the current implementation of ACES that it is not a true client/sever database model. The current implementation is modeled after obsolete legacy mainframe host computer systems, where end users sign on to the host database system via dedicated or dial-up phone lines with a "dumb" terminal. With ACES, the user's computer is using software that simply emulates a host computer terminal, for example DEC VT-220. This configuration was used extensively in the 1960-1980's. It is not typical of modern, user-friendly implementations. Major drawbacks of this configuration is that the end user's computer is essentially acting as a "dumb" terminal that connects to a remote host. All transactions and calculations are done on the remote host. The end user's computer is only used for character display and keyboard entry. Additionally, the remote host ends up wasting CPU time to handle the precise screen terminal emulation coding used to display a screen of information at the end user's computer. The software developer is substantially restricted in the available techniques to design the interface so it is easy to use and understand. In host-based systems, as with ACES, the non-intuitive end user interface consists of highly layered menus with confusing menu descriptions that require extensive keystroke manipulation and sequential screen-based processing. End users are faced with a significant learning curve to achieve proficiency.

1SUN is a trademark of Sun Microsystems, Inc.

${ }^{2}$ SPARC is a trademark of SPARC International, Inc.

${ }^{3} 0$ racle is a trademark of Oracle corporation. 


\begin{tabular}{|c|c|c|c|c|c|}
\hline \multicolumn{6}{|c|}{ DISTRIBUTION SHEET } \\
\hline & \multirow{2}{*}{\multicolumn{3}{|c|}{$\begin{array}{l}\text { From } \\
\text { S. G. Sterling }\end{array}$}} & \multicolumn{2}{|l|}{ Page 1 of 1} \\
\hline Distribution List & & & & \multicolumn{2}{|c|}{ Date $08 / 26 / 96$} \\
\hline \multirow{2}{*}{\multicolumn{4}{|c|}{$\begin{array}{l}\text { Project Title/Work Order } \\
\text { INDUSTRIAL ENGINEERING STUDY OF TANK FARM ACCESS QUALIFICAITONS } \\
\text { AND VALIDATIONS }\end{array}$}} & \multirow{2}{*}{\multicolumn{2}{|c|}{$\begin{array}{ll}\text { EDT No. } & 615551 \\
\text { ECN No. } & \text { N/A }\end{array}$}} \\
\hline & & & & & \\
\hline Name & MSIN & $\begin{array}{l}\text { Text } \\
\text { With All } \\
\text { Attach. }\end{array}$ & Text Only & $\begin{array}{l}\text { Attach./ } \\
\text { Appendix } \\
\text { Only }\end{array}$ & $\begin{array}{l}\text { EDT/ECN } \\
\text { Only }\end{array}$ \\
\hline $\begin{array}{l}\text { S. L. Bump } \\
\text { C. L. Cadwell } \\
\text { T. E. Chrisler } \\
\text { K. J. Freeman } \\
\text { J. E. Geary } \\
\text { A. W. Graves } \\
\text { R. B. Johnson } \\
\text { K. Nelson-Jenson } \\
\text { T. K. Peterson } \\
\text { R. D. Raaz } \\
\text { D. P. Reber } \\
\text { W. E. Ross } \\
\text { F. O. Strankman } \\
\text { J. H. Wicks, Jr. } \\
\text { Central Files }\end{array}$ & $\begin{array}{l}\text { T4-08 } \\
\text { S5-07 } \\
\text { L4.99 } \\
\text { S4-45 } \\
\text { S5-07 } \\
\text { E6-28 } \\
\text { S7-40 } \\
\text { S7-40 } \\
\text { G3-12 } \\
\text { R2-40 } \\
\text { T4-07 } \\
\text { S5-07 } \\
\text { R2-50 } \\
\text { R2-50 } \\
\text { A3-88 }\end{array}$ & $\begin{array}{l}x \\
x \\
x \\
x \\
x \\
x \\
x \\
x \\
x \\
x \\
x \\
X \\
x \\
x \\
x\end{array}$ & & & \\
\hline S. G. Sterling & $E 6-21$ & $x$ & & & \\
\hline
\end{tabular}

